Nevada

Environmental

Restoration

Project

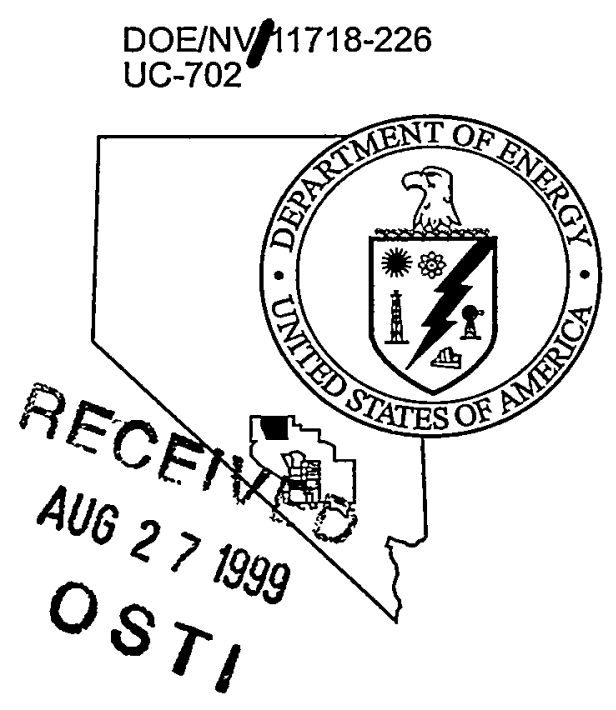

Closure Report for

Corrective Action Unit 426:

Cactus Spring Waste Trenches,

Tonopah Test Range, Nevada

Controlled Copy No.:

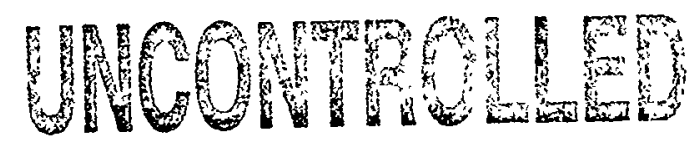

Revision No.: 0

August 1998

Approved for public release; further distribution is authorized.

Environmental Restoration

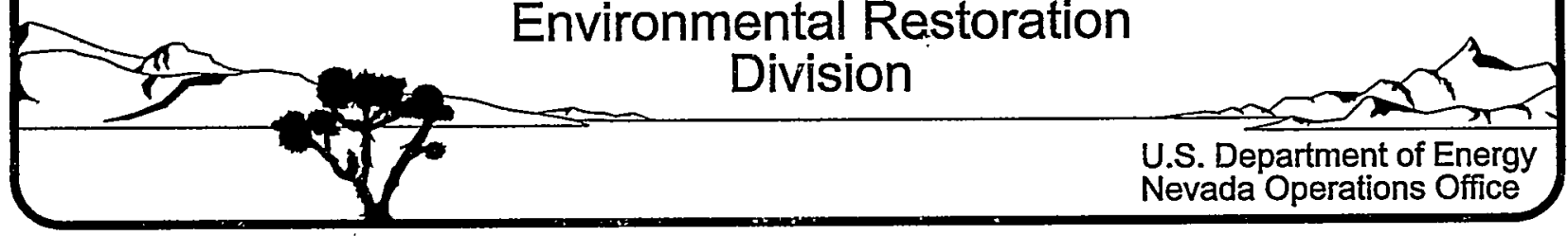


This report has been reproduced from the best available copy.

DOE and DOE contractors can obtain copies of this report from the Office of Scientific and Technical Information, P.O. Box 62, Oak Ridge, TN 37831, (423) 576-8401.

This report is publicly available from the National Technical Information Service, U. S. Department of Commerce, 5285 Port Royal Road, Springfield, VA, 22161, (703) 487-4650. 


\section{DISCLAIMER}

This report was prepared as an account of work sponsored by an agency of the United States Government. Neither the United States Government nor any agency thereof, nor any of their employees, make any warranty, express or implied, or assumes any legal liability or responsibility for the accuracy, completeness, or usefulness of any information, apparatus, product, or process disclosed, or represents that its use would not infringe privately owned rights. Reference herein to any specific commercial product, process, or service by trade name, trademark, manufacturer, or otherwise does not necessarily constitute or imply its endorsement, recommendation, or favoring by the United States Government or any agency thereof. The views and opinions of authors expressed herein do not necessarily state or reflect those of the United States Government or any agency thereof. 


\section{DISCLAIMER}

Portions of this document may be illegible in electronic image products. Images are produced from the best available original document. 


\title{
CLOSURE REPORT FOR CORRECTIVE ACTION UNIT 426: CACTUS SPRING WASTE TRENCHES TONOPAH TEST RANGE, NEVADA
}

\author{
Prepared for \\ - U. S. Department of Energy \\ Nevada Operations Office \\ Under Contract No. DE-AC08-96NV11718
}

Controlled Copy No.:

Revision: 0

Prepared by

Bechtel Nevada

Environmental Restoration Program 


\section{CLOSURE REPORT FOR CORRECTIVE ACTION UNIT 426: CACTUS SPRING WASTE.TRENCHES TONOPAH TEST RANGE, NEVADA}

Approved by: Oaud Ppeseln-Wa Janet L. Appenzeller-Wing, Project Manager Industrial Sites Subproject

Approved by:

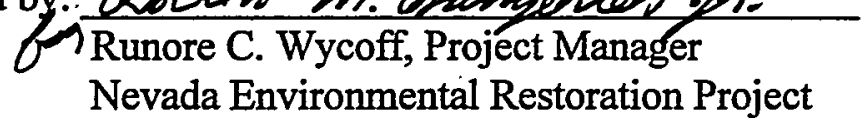

Date: $8 / 11 / 98$

Date: $8 / 11 / 98$ 


\section{TABLE OF CONTENTS}

ACRONYMS AND ABBREVIATIONS $\ldots \ldots \ldots \ldots \ldots \ldots \ldots \ldots \ldots \ldots \ldots \ldots \ldots \ldots \ldots$

EXECUTIVE SUMMARY $\ldots \ldots \ldots \ldots \ldots \ldots \ldots \ldots \ldots \ldots \ldots \ldots \ldots \ldots \ldots \ldots \ldots$

1.0 INTRODUCTION $\ldots \ldots \ldots \ldots \ldots \ldots \ldots \ldots \ldots \ldots \ldots \ldots \ldots \ldots \ldots \ldots \ldots \ldots$

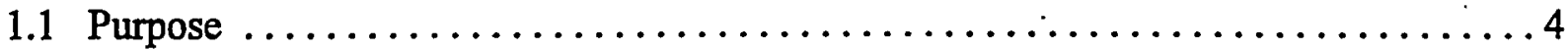

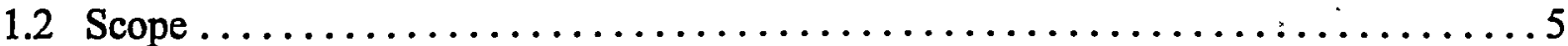

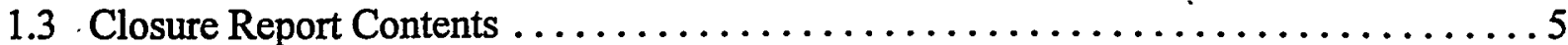

2.0 CLOSURE ACTIVITIES $\ldots \ldots \ldots \ldots \ldots \ldots \ldots \ldots \ldots \ldots \ldots \ldots \ldots \ldots \ldots \ldots \ldots$

2.1 Description of Corrective Action Activities $\ldots \ldots \ldots \ldots \ldots \ldots \ldots \ldots \ldots \ldots \ldots \ldots$

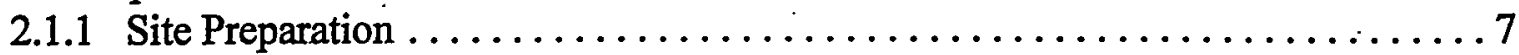

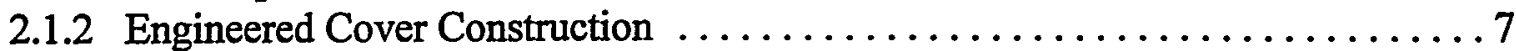

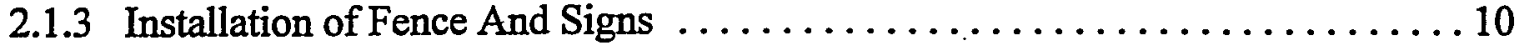

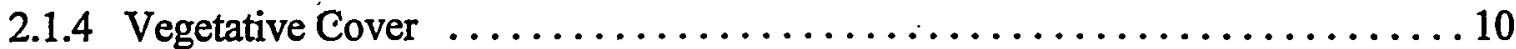

2.2 Deviations From Corrective Action Plan As Approved . . . . . . . . . . . 10

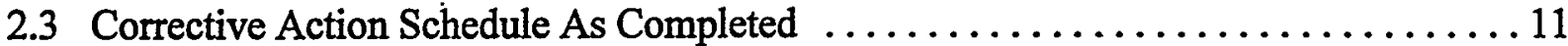

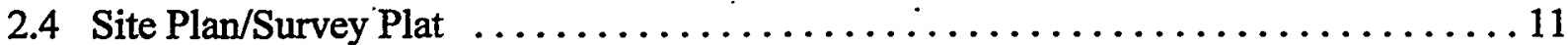

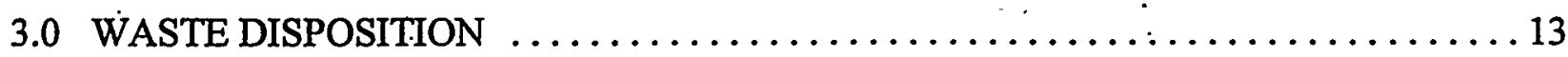

4.0 CLOSURE VERIFICATION RESULTS $\ldots \ldots \ldots \ldots \ldots \ldots \ldots \ldots \ldots \ldots \ldots \ldots \ldots$

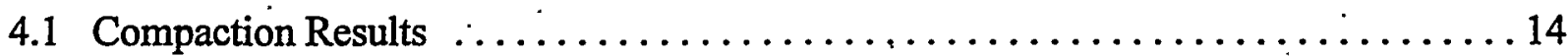

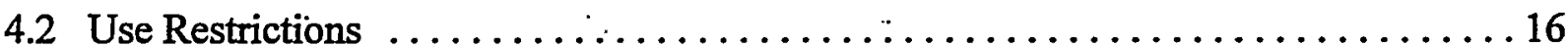

5.0 POST-CLOSURE MONITORING PLAN $\ldots \ldots \ldots \ldots \ldots \ldots \ldots \ldots \ldots \ldots \ldots$

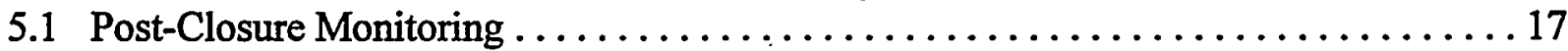

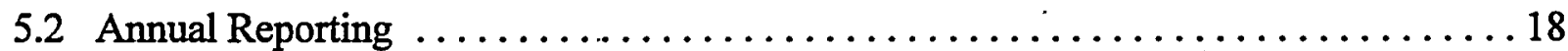

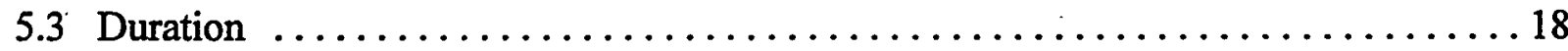

6.0 CONCLUSIONS AND RECOMMENDATIONS $\ldots \ldots \ldots \ldots \ldots \ldots \ldots \ldots \ldots \ldots$

6.1 Conclusions ..................................... 19

6.2 Recommendations . . . . . . . . . . . . . . . . . . . . . . 19

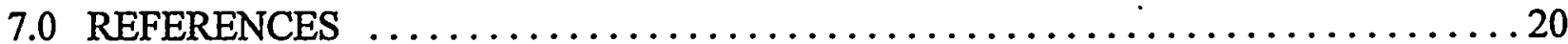




\section{TABLE OF CONTENTS (continued)}

\section{FIGURES}

FIGURE 1 - LOCATION OF CACTUS SPRING WASTE TRENCHES $\ldots \ldots \ldots \ldots \ldots \ldots$

FIGURE 2 - SITE MAP FOR CACTUS SPRING WASTE TRENCHES . . . . . . . . . 3

FIGURE 3 - ENGINEERED COVER FILL HORIZONS $\ldots \ldots \ldots \ldots \ldots \ldots \ldots \ldots$

FIGURE 4 - CORRECTIVE ACTION SCHEDULE AS COMPLETED . . . . . . . . . . . 12

\section{TABLES}

TABLE 1 - SEED MIX FOR REVEGITATION $\ldots \ldots \ldots \ldots \ldots \ldots \ldots \ldots \ldots \ldots \ldots$

TABLE 2 - COMPACTION TEST RESULTS $\ldots \ldots \ldots \ldots \ldots \ldots \ldots \ldots \ldots \ldots \ldots$

\section{APPENDICES}

APPENDIX A - AS-BUILT ENGINEERING DRAWINGS

APPENDIX B - USE RESTRICTION DOCUMENTATION

APPENDIX C - GEOTECHNICAL TEST RESULTS

APPENDIX D - POST CLOSURE MONITORING CHECKLIST 


\section{ACRONYMS AND ABBREVIATIONS}

CADD Corrective Action Decision Document

CAIP Corrective Action Investigation Plan

CAS Corrective Action Site

CAP Corrective Action Plan

CAU - Corrective Action Unit

cm centimeter

$\mathrm{cm} / \mathrm{sec} \quad$ centimeters/second .

COCs Constituents of Concern

CR Closure Report

DOE U.S. Department of Energy

DOE/NV U.S. Department of Energy, Nevada Operations Office

EPA U.S. Environmental Protection Agency

FFACO Federal Facilities Agreement and Compliance Order

$\mathrm{ft} \quad$ feet

$\mathrm{ft}^{3} \quad$ cubic feet

in inch

in/sec inches/second

$\mathrm{km} \quad$ kilometer

$\mathrm{kg} / \mathrm{ha} \quad$ kilograms/hectar

lbs/ac pounds/acre 


\section{ACRONYMS AND ABBREVIATIONS (continued)}

$\mathrm{m}$

meter

$\mathrm{m}^{3} \quad$ cubic meter

mi mile

NDEP Nevada Division of Environmental Protection

PRG Preliminary Remediation Goal

TTR Tonopah Test Range

USAF United States Air Force

$\mathrm{yd}^{3} \quad$ cubic yard 
This Closure Report provides the documentation for closure of the Cactus Spring Waste Trenches Corrective Action Unit (CAU) 426. The site is located on the Tonopah Test Range, approximately 225 kilometers (140 miles) northwest of Las Vegas, Nevada.

CAU 426 consists of one Corrective Action Site (CAS) which is comprised of four waste trenches (CAS Number RG-23-001-RGCS). The trenches were excavated to receive solid waste generated in support of Operation Roller Coaster, primarily the Double Tracks Test in 1963, and were subsequently backfilled. The Double Tracks Test involved the use of live animals to assess the biological hazards associated with the non-nuclear detonation of plutonium-bearing devices (i.e., inhalation uptake of plutonium aerosol) (DOE, 1996).

The remedial alternative proposed in the Corrective Action Decision Document (CADD) for the site was "Capping" (DOE, 1997a). The Nevada Division of Environmental Protection (NDEP)approved Corrective Action Plan (CAP) proposed the "Capping" methodology (DOE, 1997b). The closure activities were completed in accordance with the approved CAP and consisted of constructing an engineered cover in the area of the trenches, constructing/planting a vegetative cover, installing a perimeter fence and signs, implementing restrictions on future use, and preparing a Post-Closure Monitoring Plan:

Since closure activities for CAU 426 have been completed in accordance with the Nevada Division of Environmental Protection-approved CAP (DOE, 1997b) as documented in this Closure Report, the U.S. Department of Energy, Nevada Operations Office (DOE/NV) requests:

- $\quad$ CAU 426 be moved from Appendix III to Appendix IV of the Federal Facility Agreement and Consent Order.

- NDEP provide a Notice of Completion to the DOE/NV. 


\subsection{INTRODUCTION}

The U:S. Department of Energy, Nevada Operations Office (DOE/NV) operates the Nevada Test Site and entered into a trilateral agreement with the state of.Nevada and the U.S. Defense Special Weapons Agency. The trilateral agreement, the Federal Facilities Agreement and Consent Order (FFACO), provides a framework for identifying, characterizing, remediating, and closing DOE/NV environmental sites in Nevada (NDEP, 1996). Corrective Action Units (CAUs) have been identified in the FFACO at the Tonopah Test Range (TTR) which is currently operated by the DOE/Albuquerque Operations Office and U.S. Air Force (USAF).

This Closure Report (CR) provides documentation for the closure of the Cactus Spring Waste Trenches Corrective Action Unit (CAU) 426. The site is located on the TTR, approximately 225 kilometers $(\mathrm{km})$ (140 miles [mi]) northwest of Las Vegas, Nevada. See Figure 1 for the site location.

CAU 426 consists of one Corrective Action Site (CAS) comprised of four waste trenches (CAS Number RG-23-001-RGCS). The trenches were excavated to receive solid waste generated in . support of Operation Roller Coaster, primarily the Double Tracks Test in 1963. The Double Tracks Test involved the use of live animals to assess the biological hazards associated with the non-nuclear detonation of plutonium-bearing devices (i.e., inhalation uptake of plutonium aerosol) (DOE, 1996). The trenches were subsequently backfilled. Each trench is approximately 36 meters $(\mathrm{m})$ (118.1 feet [ft]) long by $3 \mathrm{~m}$ to $5 \mathrm{~m}(9.8 \mathrm{ft}$ to $16.4 \mathrm{ft})$ wide by $3 \mathrm{~m}$ to $4.5 \mathrm{~m}(9.8 \mathrm{ft}$ to $14.8 \mathrm{ft}$ ) deep. A site map is provided as Figure 2.

Detailed information of the site history and results of the investigation activities can be found in the Corrective Action Investigation Plan (CAIP) (DOE, 1996), and the Corrective Action Decision Document (CADD) (DOE, 1997a).

Site investigation results indicated the following:

- Small quantities of sanitary waste were observed in the drill cores collected from the trenches. The waste materials included wood, glass, metal, animal bone fragments, and paint chips. The waste was predominantly found from $0.9 \mathrm{~m}(3 \mathrm{ft})$ to $2.1 \mathrm{~m} \mathrm{(7ft)} \mathrm{below}$ the surface.

- No visual or radiological evidence was observed indicative of disposal of the animal shrouds in the trenches. 


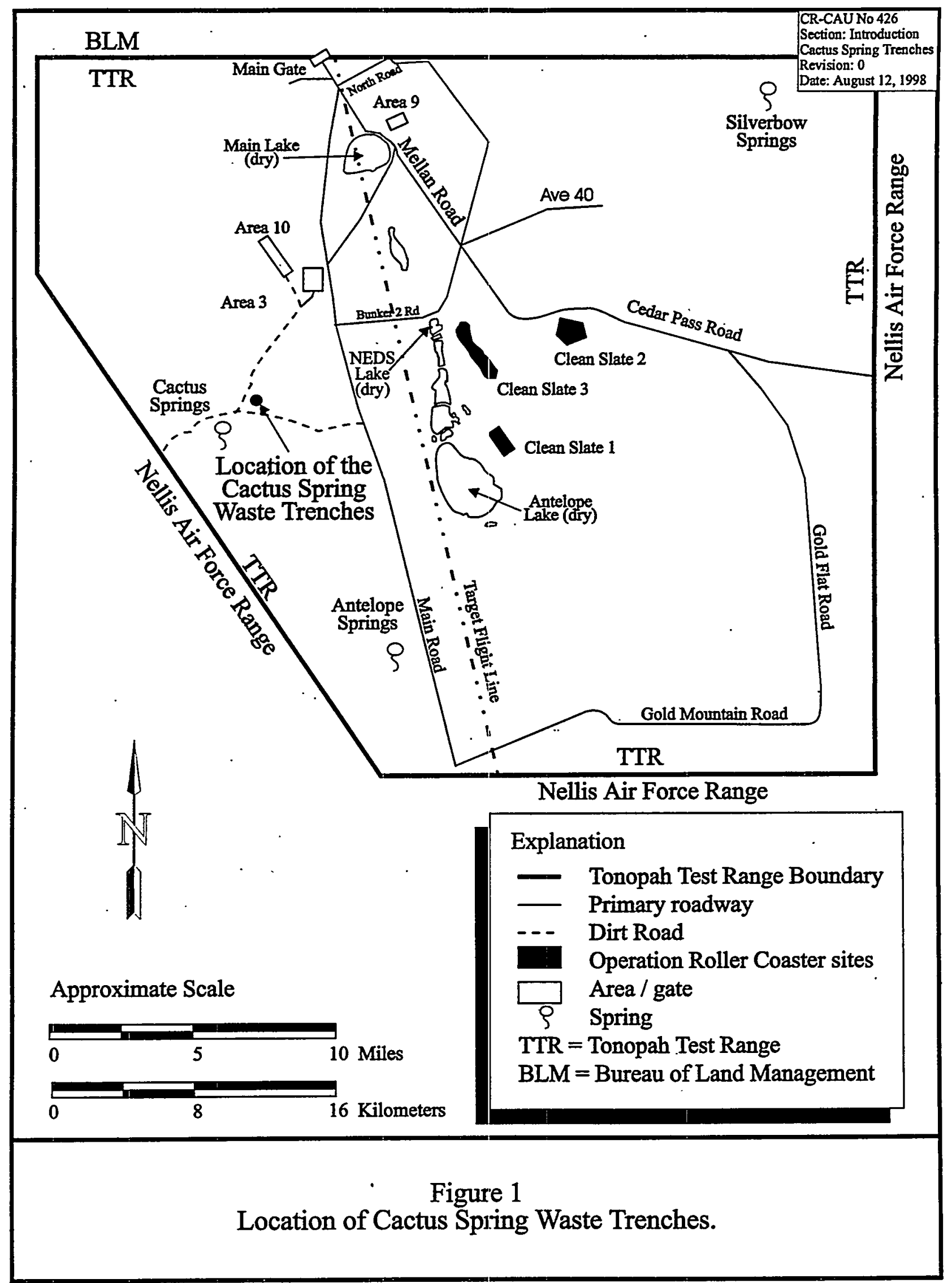




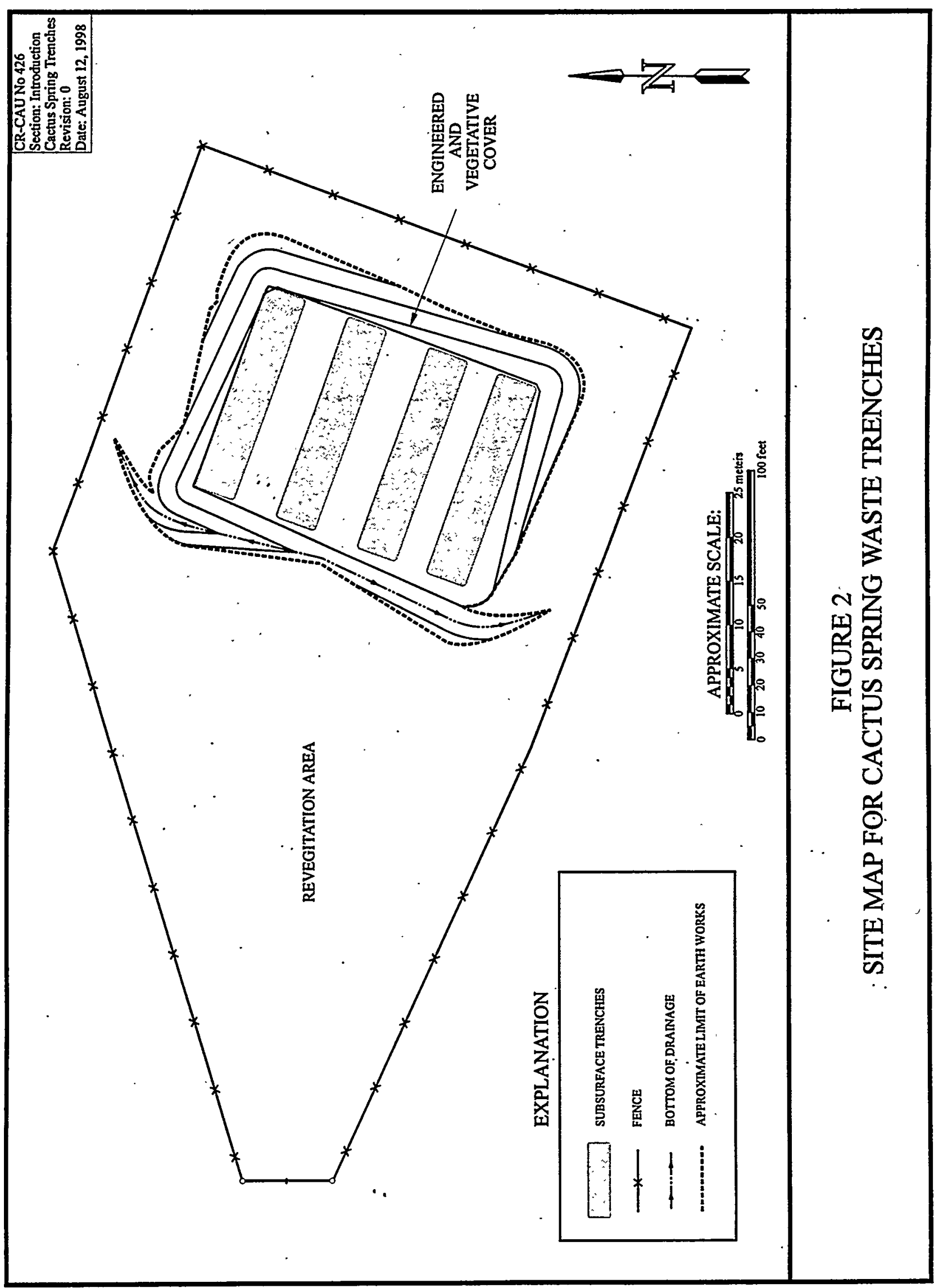


- $\quad$ No concentrations of constituents of concern (COCs) were detected above U.S. Environmental Protection Agency (EPA) Region IX Preliminary Remediation Goals (PRGs) (EPA, 1996). Most of the detected COCs were estimated values associated with laboratory contamination or were naturally occurring. One soil sample collected for Total Petroleum Hydrocarbon analysis (as diesel) with a result of 5,300 milligrams per kilogram $(\mathrm{mg} / \mathrm{kg})$ was assessed to be a spurious data point.

- The alluvial/fill material comprising the trench cover and the native material below the trenches have relatively low hydraulic conductivities ranging from $5.9 \times 10^{-4}$ centimeters $/ \mathrm{second}(\mathrm{cm} / \mathrm{sec})\left(2.3 \times 10^{-4}\right.$ inches $\left./ \mathrm{second}[\mathrm{in} / \mathrm{sec}]\right)$ to $2.5 \times 10^{-8} \mathrm{~cm} / \mathrm{sec}(9.8$ $\left.\mathrm{x} 10^{-9} \mathrm{in} / \mathrm{sec}\right)$.

Remedial alternatives were proposed in the CADD based upon the results of the investigation activities. The proposed remedial alternatives were "No Action, Access Restrictions, Excavation and Capping, and Capping". The Nevada Division of Environmental Protection (NDEP) approved-CADD identified "Capping" as the selected remedial alternative. The "Capping" alternative was proposed to consist of the construction of a vegetative, engineered cover, installation of a fence, and restrictions on future use (DOE, 1997a).

DOE/NV expedited the closure schedule in Fiscal Year 1997 and proposed the closure methodology for the selected remedial alternative to the NDEP in a Draft Corrective Action Plan (CAP) in August, 1997. Based upon an expedited review by and comments received from the NDEP for the Draft CAP (NDEP, 1997a), DOE/NV implemented the field closure activities between September 17, 1997 and October 30, 1997. The Final CAP (DOE, 1997b) was transmitted to the NDEP on September 16,1997. The NDEP provided an expedited review of the Final CAP and approved the proposed activities on September 29, 1997 (NDEP, 1997b).

\subsection{PURPOSE}

The purpose of this $\mathrm{CR}$ is to:

- Document the closure activities and provide the information collected as proposed in the CAP (DOE, 1997b).

- $\quad$ Obtain a Notice of Completion from the NDEP.

- Recommend the movement of CAU 426 from Appendix III to Appendix IV of the FFACO. 


\subsection{SCOPE}

The following is the scope of the closure actions implemented for CAU 426:

- Install an engineered cover over the trenches.

- Plant native shallow rooted plants/grasses on the engineered cover.

- Install a fence with signs on the perimeter of the site.

Coordinate closure of the site with the USAF because of the location of the site and use restrictions.

- $\quad$ Provide documentation (this report) of remedial activities and a Post-Closure Monitoring Plan.

\subsection{CLOSURE REPOORT CONTENTS}

This $\mathrm{CR}$ is divided into the following sections:

- Section 1.0 - Introduction: Site background, purpose, scope, and report contents

- Section 2.0 - Closure Activities: Corrective action activities; deviations from the CAP as approved, corrective action schedule as completed, and site plan

- Section 3.0 - Waste Disposition

- Section 4.0 - Closure Verification Results

- Section 5.0 - Post-Closure Monitoring Plan

- Section 6.0 - Conclusions and Recommendations

- Section 7.0 - References

- Appendix A - Engineering Drawings

- Appendix B - Use Restriction Documentation

- Appendix C - Geotechnical Test Results

- Appendix D - Post-Closure Monitoring Checklist 
This report was developed using information and guidance from the following documents:

- Corrective Action Investigation Plan: Cactus Spring Waste Trenches, Revision 0, DOE, 1996.

- Corrective Action Decision Document For the Cactus Spring Trenches, Revision 1, July 1997, DOE, 1997a.

- Corrective Action Plan For CAU No. 426: Cactus Spring Waste Trenches, Tonopah Test Range, DOE, $1997 \mathrm{~b}$.

- Nevada Environmental Restoration Project, Health and Safety Plan Revision 2, DOE, 1996.

- Nevada Environmental Restoration Project. Industrial Sites, Quality Assurance Project Plan, Nevada Test Site, Revision 1, DOE, 1996.

- Nevada Environmental Restoration Project, Project Management Plan, Revision 0, DOE, 1994.

- Tonopah Test Range Closure Sites Revegitation Plan, DOE, 1997. 


\subsection{CLOSURE ACTIVITIES}

This section of the CR details the specific activities involved in the closure of the Cactus Spring Waste Trenches CAU 426 (CAS Number RG-23-001-RGCS). This section also includes the rationale for deviations from the approved CAP (DOE, 1997b) and a detailed schedule of site activities as completed.

\subsection{DESCRIPTION OF CORRECTIVE ACTION ACTIVITIES}

\subsubsection{Site Preparation}

Prior to the start of field closure activities, a soil sample was collected for geotechnical testing from the borrow pit located approximately $9 \mathrm{~km}(5.5 \mathrm{mi})$ northeast of the site (see Engineering Drawings in Appendix A for the location of the borrow pit). The soil sample was collected to determine the maximum density (ASTM, 1997a [modified proctor test]) for compaction testing in the area of the trenches.

Soils from the site and borrow pit were observed by the site geologist to be a silty sand with gravel. Sieve analysis (ASTM, 1997b) of the sample collected from the borrow pit confirmed the borrow pit soil to be a silty sand with gravel. Geotechnical test results are discussed in Section 4.0. Since the borrow and site soil were similar, size reduction of the borrow material was not required for the vegetative covers.

Prior to placement of soil in the area of the trenches for construction of the engineered cover, water was applied to the site with the water truck for dust control and compaction purposes. Additionally, the engineered cover area was compacted with repeated passes using the water truck to provide a base for compaction. Minor depressions (up to approximately 10 centimeters (cm) [4 inches (in)]) were observed in the areas of the trenches after compaction activities with the water truck.

\subsubsection{Engineered Cover Construction}

Belly dump trucks were used to transport the soil to the site from the borrow pit. Approximately 840 cubic meters $\left(\mathrm{m}^{3}\right)\left(1,100\right.$ cubic yards [yd $\left.\left.\mathrm{y}^{3}\right]\right)$ of soil were transported to the site for area grading, backfilling of the minor depressions in the areas of the trenches, and construction of engineered/vegetative cover. Water for dust suppression and construction activities was obtained from the Roller Coaster Well located approximately $7 \mathrm{~km} \mathrm{(4.3} \mathrm{mi)} \mathrm{east} \mathrm{of} \mathrm{the} \mathrm{site} \mathrm{(see}$ Engineering Drawings in Appendix A for the location of the well). Water was introduced to and mixed with the soil at the borrow pit as dust control. Approximately 272,520 liters $(72,000$ 
gallons) of water was used for soil preparation and dust suppression activities at the site and on the access road to the site.

Diversion channels were constructed by excavating the existing soil to channel precipitation runoff away from the site and limit precipitation run-on to the engineered cover area (Appendix A).

Compaction of the soil at the site was conducted using a grader and traffic from the belly dump trucks. The soil fill was placed in approximately $0.2 \mathrm{~m}$ (8 in) lifts over the entire cover area and compacted to minimize subsidence and decrease the permeability of the backfill relative to the native, undisturbed soils as required in the CAP (DOE, 1997b). Fill was placed at the site in the following three horizons (see Figure 3):

- "Bottom" compacted fill horizon: the compacted soil horizon between the compacted soil base (existing site soil) and "top" compacted fill horizon. The "bottom" compacted fill horizon ranged from $0.2 \mathrm{~m}$ to $0.3 \mathrm{~m}(0.7 \mathrm{ft}$ to $1 \mathrm{ft})$ in thickness and consists of approximately two compacted $0.2 \mathrm{~m}:(8 \mathrm{in})$ lifts of loose soil.

- "Top" compacted fill horizon: the compacted fill horizon between the "bottom" compacted fill horizon and the vegetative cover. The "top" compacted fill horizon ranged from $0.2 \mathrm{~m}$ to $0.3 \mathrm{~m}(0.7 \mathrm{ft}$ to $1 \mathrm{ft})$ and consists of approximately two compacted $0.2 \mathrm{~m}(8 \mathrm{in})$ lifts of loose soil.

- Vegetative cover: the fill horizon above the "top" compacted fill horizon prepared for the planting of native shallow rooted plants/grasses.

Field density (compaction) tests (ASTM, 1995c [nuclear density tests]) were conducted in the "bottom" and "top" compacted fill horizons after compaction activities were completed. Compaction results are discussed in Section 4.1.

After compaction results were determined to exceed the minimum requirement of 80 percent of the maximum density in the "bottom" compacted fill horizon, additional fill was placed and compacted. The additional fill was placed on the cover area in approximate $0.2 \mathrm{~m}$ ( $8 \mathrm{in}$ ) lifts and compacted. Up to two compacted lifts of soil were required to complete the "top" compacted fill horizon. The top of the compacted area of the engineered cover is approximately $0.3 \mathrm{~m}$ to $0.5 \mathrm{~m}$ [1.0 ft to $1.5 \mathrm{ft}]$ ) below the final grade of the vegetative cover. After compaction results were determined to exceed the minimum requirement of 80 percent of the maximum density in the "top" compacted fill horizon, additional fill was placed for the construction of the vegetative cover (see Section 2.1.4 for discussion regarding construction of the vegetative cover). 


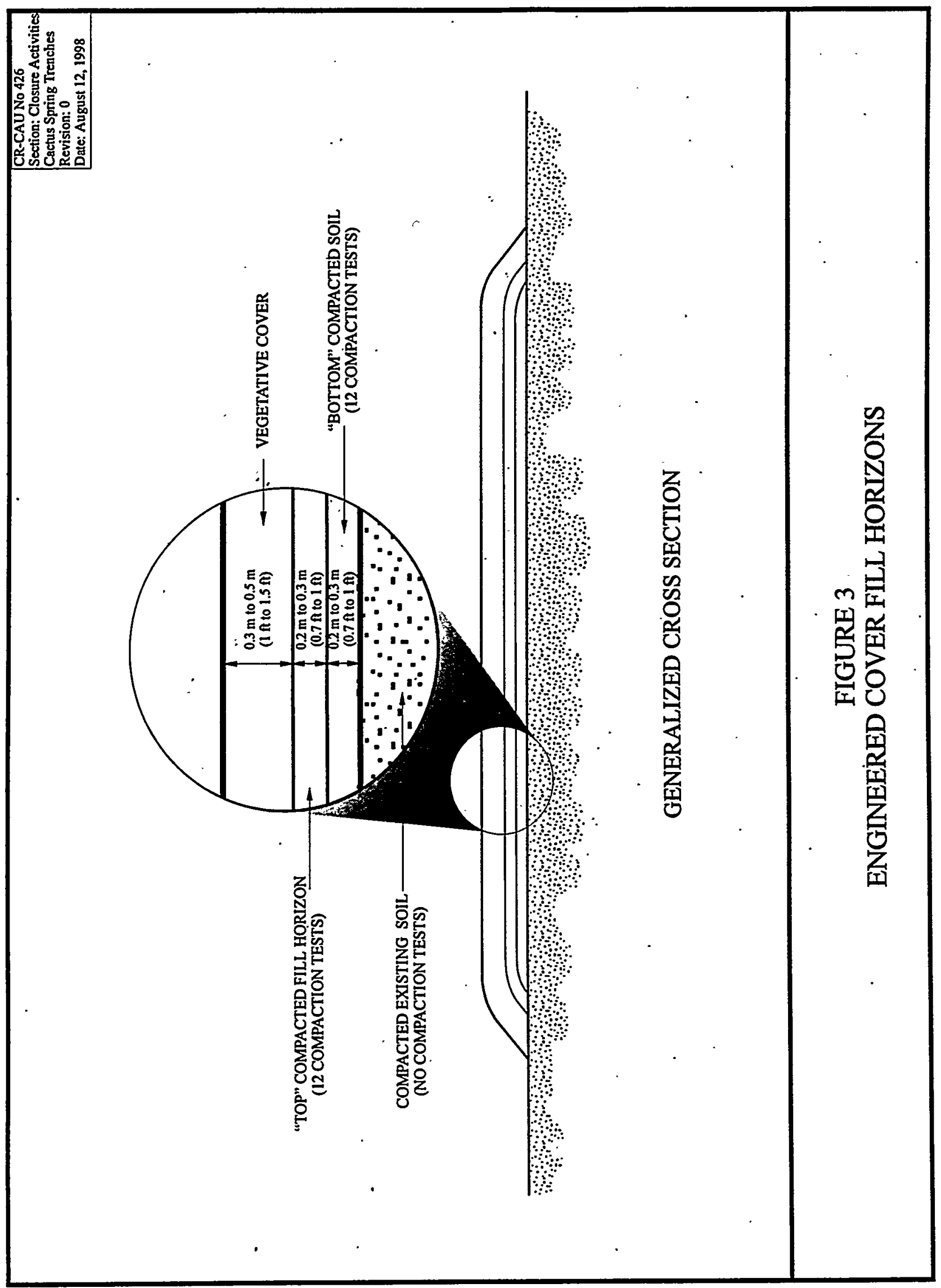




\subsubsection{Installation of Fence and Signs}

To allow native plant species to establish and develop and to inhibit unauthorized excavation into the cover, a three-strand barbed wire fence with a woven wire mesh ( $2.5 \mathrm{~cm}$ [1 in] weave) base was installed at the perimeter of the site. The woven wire mesh is approximately $0.6 \mathrm{~m}(2 \mathrm{ft})$ tall. The location of the fence can be found in Appendix A. Signs were posted near the corners and center area of each side of the fence indicating "Vegetation Area, No Excavation."

\subsubsection{Vegetative Cover}

After the density tests were conducted in the "top" compacted fill horizon $(0.3 \mathrm{~m}$ to $0.5 \mathrm{~m}[1.0 \mathrm{ft}$ to $1.5 \mathrm{ft}$ ] below the final grade), the soil for the vegetative cover was placed and moderately compacted. Compaction tests were not proposed or required in the vegetative cover since the area would be ripped and disked prior to planting.

Surface preparation for planting consisted of ripping the cover areas and area within the fence with a grader to an approximate depth of $0.4 \mathrm{~m}(1.3 \mathrm{ft})$ and harrowing with a spring-tooth harrow. The schedule of vegetative cover construction and planting activities can be found in Figure 4.

Polyacrylamide gel was applied at the same time as seeding at an approximate rate of 22 kilograms per hectar ( $\mathrm{kg} / \mathrm{ha})$ ( 20 pounds per acre [lbs/ac]) to assist in the retention of soil moisture for seed germination and plant development. The seed mixture (Table 1) was planted in October to ensure dormancy breaking requirements would be met, and that the seed would be in the ground prior to the winter precipitation. After the seeds were planted, straw was broadcast on the site at an approximate rate of $4,500 \mathrm{~kg} / \mathrm{ha}(4,000 \mathrm{lbs} / \mathrm{ac})$ with a straw blower. The straw was subsequently punched into the soil with a tractor-clrawn disk crimper. The straw is used as a mulch to add organic matter to the soil and is a barrier to reduce wind and water erosion.

\subsection{DEVIATIONS FROM CORRECTIVE ACTION PLAN AS APPROVED}

No deviations from the approved CAP (DOE, 1997b) occurred. 


\section{TABLE 1 - SEED MIX FOR REVEGETATION}

\begin{tabular}{|c|c|c||}
\hline CoMMON NAME & SCIENTIFICNAME & $\begin{array}{c}\text { QUANTMY INMTX } \\
\text { kg/ha(ibs/ac) }\end{array}$ \\
\hline \hline Budsage & Artemisia spinescens & $0.5(0.4)$ \\
\hline Shadscale & Atriplex confertifolia & $17.2(15.4)$ \\
\hline Winterfat & Ceratoides lanata & $14.8(13.2)$ \\
\hline Fourwing Saltbush & Atriplex canescens & $3.1(2.8)$ \\
\hline Galleta & Hilaria jamesii & $7.4(6.6)$ \\
\hline Indian Ricegrass & Oryzopsis hymenoides & $4.9(4.4)$ \\
\hline Bottlebrush Squirreltail & Sitanion hystrix & $3.5(3.1)$ \\
\hline Desert Globemallow & Sphaeralcea ambigua & $0.4(0.3)$ \\
\hline
\end{tabular}

\subsection{CORRECTIVE ACTION SCHEDULE AS COMPLETED}

The corrective action activities were completed in a timely manner. A detailed schedule of the project activities as completed can be.found in Figure 4.

\subsection{SITE PLAN/SURVEY PLAT}

Figure 1 provides the location of CAU 426, and Figure 2 is the site map. As-Built engineering drawings can be found in Appendix A. 


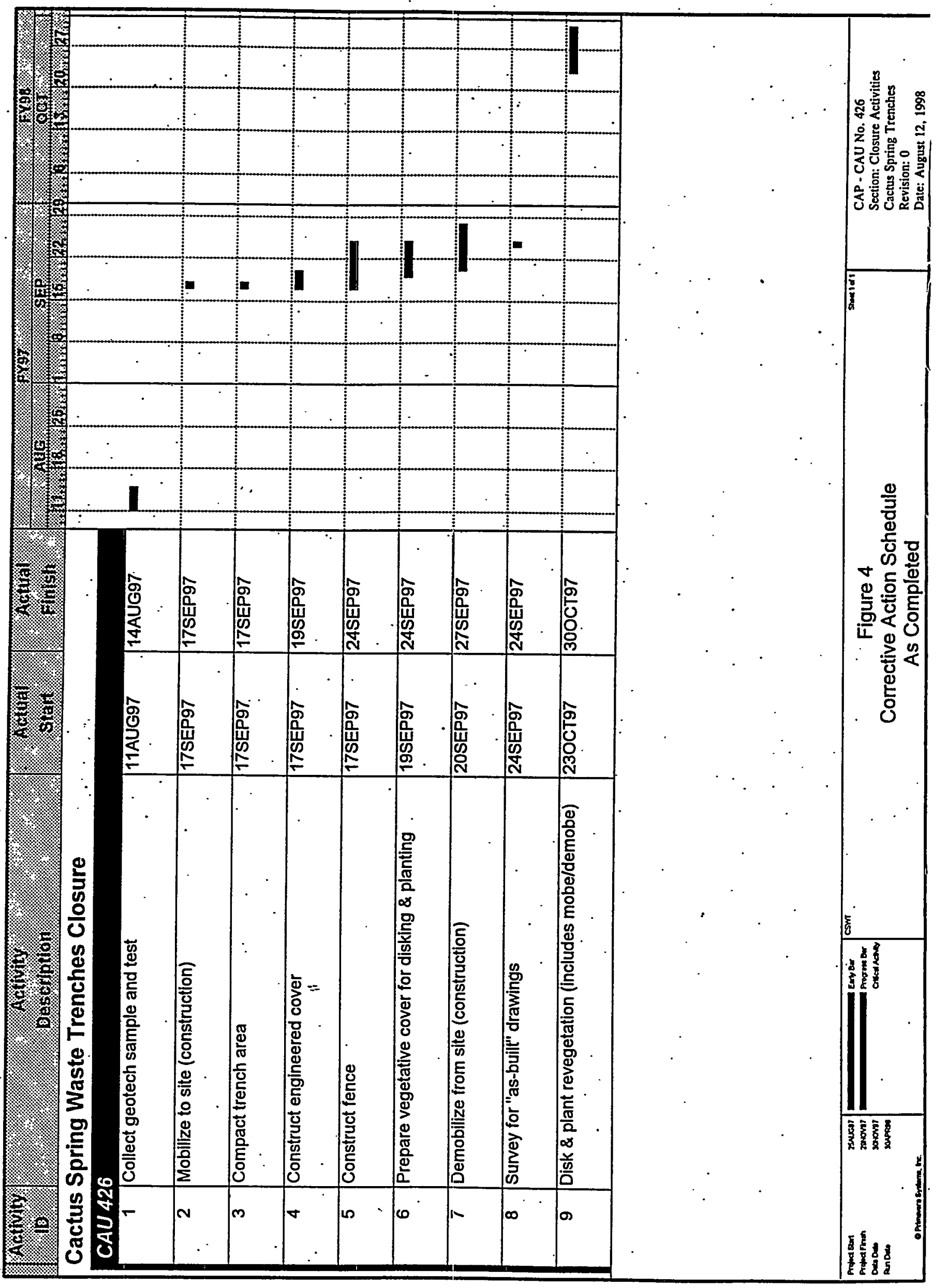




\subsection{WASTE DISPOSITION}

A small volume of construction debris was generated at the site from the fencing activities. The construction debris consisted of paper, plastic, wire, and wood (less than $0.1 \mathrm{~m}^{3}$ [ 5 cubic feet $\left.\left(\mathrm{ft}^{3}\right)\right]$ ). The construction debris was disposed in the TTR USAF landfill by Kirk-Myer, Inc. Services.

Decontamination and personnel protective equipment wastes were not generated since closure activities did not expose or contact any of the trench contents. 


\subsection{CLOSURE VERIFICATION RESULTS}

\subsection{COMPACTION RESULTS}

One maximum density test (ASTM, 1997a) and sieve analysis (ASTM, 1997b) was conducted on a sample collected from the borrow pit. The borrow pit sample was collected for the closure activities conducted this site and at CAU 404 (TTR Roller Coaster Sewage Lagoons and North Disposal Trench). The maximum density of the borrow pit soil was $1,970 \mathrm{~kg} / \mathrm{m}^{3}\left(123.0 \mathrm{lb} / \mathrm{ft}^{3}\right)$. The maximum density was used to determine the percent compaction from the field density tests (ASTM, 1997c [nuclear density testing]). Geotechnical test results can be found in Appendix C.

Through observations by the site geologist and sieve analysis, the borrow pit and site soil were determined to be a silty sand with gravel. Since the soils were similar, size reduction was not required for the soil used for the vegetative cover.

The compaction requirement for the engineered cover was a minimum of 80 percent of the maximum density (DOE, 1997b). Construction activities for the engineered cover and vegetative cover are described in Sections 2.1.2 and 2.1.4, respectively. Compaction test results are summarized in Table 2 and presented in Appendix C. The compaction test locations can also be found in Appendix $\mathrm{C}$. The following discussion provides information regarding the field density tests for the compacted fill horizons of the engineered cover (refer to Figure 3 for the relative locations of the fill horizons).

Three density tests were conducted in the area of each trench in the "bottom" compacted fill horizon for a total of twelve tests as proposed in the CAP (DOE, 1997b). Since the compacted thickness of the "bottom" compacted fill horizon varied between approximately $0.2 \mathrm{~m}$ to $0.3 \mathrm{~m}$ ( 8 in to 12 in), $20 \mathrm{~cm}$ ( 8 in) deep field density tests were conducted to reduce the potential of interference from the underlying native site soils. The compaction results in the "bottom" compacted fill horizon exceeded the 80 percent requirement and ranged from 89.8 to 96.9 percent compaction.

After compaction testing the "bottom" compacted fill horizon, additional fill was placed and compacted that comprised the "top" compacted fill horizon. The additional fill was placed on the cover area in approximate $0.2 \mathrm{~m}$ (8 in) lifts and compacted. Up to two compacted lifts were required to complete the "top" compacted fill horizon. For the discussion regarding the engineered cover construction activities see Section 2.1.2.

A total of twelve field density tests (three $30 \mathrm{~cm}$ [12 in] tests in each trench area) were conducted in the "top" compacted fill horizon. Selection of the $30 \mathrm{~cm}$ (12 in) test depth was based upon the compacted thickness of the "top" compacted fill horizon (ranged from approximately $0.2 \mathrm{~m}$ to $0.3 \mathrm{~m}$ ( $0.7 \mathrm{ft}$ to $12 \mathrm{in})$ depending upon the fill and grade requirements of the cover area). The 
TABLE 2 - COMPACTION TEST RESULTS

\begin{tabular}{|c|c|c|c|c|}
\hline $\begin{array}{l}\text { TEST } \\
\text { LOCATION }\end{array}$ & $\begin{array}{l}\text { LAB } \\
\text { NUMBER } \\
\end{array}$ & $\begin{array}{r}\text { COMPACTED } \\
\text { HIIL } \\
\text { HORIZON }\end{array}$ & $\begin{array}{c}\text { TEST DEPTH } \\
\ddots \\
\vdots \\
\end{array}$ & $\begin{array}{l}\text { PERCENT } \\
\text { COMPACTION } \\
\end{array}$ \\
\hline 1 & 869 & Bottom & $20 \mathrm{~cm}(8 \mathrm{in})$ & 89.8 \\
\hline 2 & 870 & Bottom & . $20 \mathrm{~cm}(8 \mathrm{in})$ & 90.5 \\
\hline 3 & 871 & Bottom & $20 \mathrm{~cm}(8 \mathrm{in})$ & 95.9 \\
\hline 4 & 872 & Bottom & $20 \mathrm{~cm}(8 \mathrm{in})$ & 92.6 \\
\hline 5 & 873 & Bottom & $20 \mathrm{~cm}(8 \mathrm{in})$ & 96.9 \\
\hline 6 & 874 & Bottom & $20 \mathrm{~cm}(8 \mathrm{in})$ & 95.9 \\
\hline 7 & 875 & Bottom & $20 \mathrm{~cm}(8 \mathrm{in})$ & $94.8^{\circ}$ \\
\hline 8 & 876 & Bottom & $20 \mathrm{~cm}(8 \mathrm{in})$ & 95.1 \\
\hline 9 & 877 & Bottom & $20 \mathrm{~cm}(8 \mathrm{in})$ & 92.8 \\
\hline 10 . & 878 & Bottom & $20 \mathrm{~cm}(8 \mathrm{in})$ & 93.1 \\
\hline 11 & 879 & Bottom & $20 \mathrm{~cm}(8 \mathrm{in})$ & 94.3 \\
\hline 12 & 880 & Bottom & $20 \mathrm{~cm}(8 \mathrm{in})$ & 95.7 \\
\hline 1 & 881 & Top & $30 \mathrm{~cm}$ (12 in) & 97.4 \\
\hline 2 & 882 & Top & $30 \mathrm{~cm}$ (12 in) & 93.1 \\
\hline 3 & 883 & Top & $30 \mathrm{~cm}$ (12 in) & 93.7 \\
\hline 4 & 884 & Top & $30 \mathrm{~cm}$ (12 in) & 95.1 \\
\hline 5 & 885 & Top & $30 \mathrm{~cm}$ (12 in) & 94.7 \\
\hline 6 & .886 & Top & $30 \mathrm{~cm}$ (12 in) & 93.3 \\
\hline 7 & 887 & Top. & $30 \mathrm{~cm}$ (12 in) & 96.0 \\
\hline 8 & 888 & Top & $30 \mathrm{~cm}(12 \mathrm{in})$ & 95.2 \\
\hline 9 & 889 & Top & $30 \mathrm{~cm}$ (12 in) & 95.2 \\
\hline 10 & 890 & Top & $30 \mathrm{~cm}(12 \mathrm{in})$ & 94.0 \\
\hline 11 & 891 & Top & $30 \mathrm{~cm}$ (12 in) & 93.6 \\
\hline 12 & 892 & Top & $30 \mathrm{~cm}$ (12 in) & 94.1 \\
\hline
\end{tabular}

Notes: 1 - Test Locations can be found in Appendix C.

2- See Section 2.1.2 for a discussion regarding the fill horizons of the engineered cover. 
compaction results exceeded the 80 percent requirement and ranged from 93.1 to 97.4 percent compaction. Field densities were not conducted in the vegetative cover since the area was to be ripped and disked prior to planting.

As-built surveying of the surface of the vegetative cover areas was completed and indicated that the covers were constructed as proposed in the approved CAP (DOE, 1997b).

\subsection{USE RESTRICTIONS}

Closure activities conducted at the site were coordinated with and acknowledged by the USAF (see Appendix B for USAF acknowledgment letter and CAU Use Restriction Form).

The Use Restriction Form was transmitted to the USAF on August 6, 1998 for recordation. After recordation, the USAF will provide the DOE/NV and NDEP with a confirmation of the recordation.

The future use of any land related to this CAU, as described in Appendix B, is restricted from any DOE or USAF activity that may alter or modify the containment control as identified in this $\mathrm{CR}$ or other documentation for this CAU unless appropriate concurrence is obtained in advance. 


\subsection{POST-CLOSURE MONITORING PLAN}

Post-closure monitoring of the covers is intended to determine:

- If maintenance and repairs to the perimeter fence are required.

- If remedial action is necessary to establish a vegetative cover.

- If maintenance and repairs to the engineered cover is required.

- When cessation to post-closure monitoring can be proposed.

\subsection{POST-CLOSURE MONITORING}

The monitoring will consist of biannual (twice per year) visual inspections of:

- The cover for condition (subsidence, significant erosion, unauthorized excavation, etc.) and plant development.

- The fence and signs to determine if repairs are required.

Additional, nonscheduled.inspections may be required after severe weather events such as heavy rainfall, flash flooding, and high winds. Any identified maintenance and repair requirements will be remedied within 90 days of discovery and documented in writing at the time of repair.

Additional revegetation work would be conducted during the next revegetation window (October to February).

Intrusion into or sampling of the trench contents is not proposed during the post-closure monitoring period.

Monitoring of the vegetative cover will be conducted during the first, third, and fifth year after revegetation. Monitoring during the first year will determine if germination of seeded plant species has occurred. By the third year, plant establishment will be evaluated. By the fifth year, long-term survival can be predicted. Concurrently, wildlife use of the site will be evaluated with the objective of determining if burrowing animals have moved onto the site and to what depth they might be expected to penetrate the cover. The erosion condition of the soil will be evaluated using a qualitative erosion condition classification developed by the U.S. Bureau of Land Management. Information gathered will be compared to natural conditions and will be used in assessing whether or not remedial action is necessary so that a viable vegetative cover is established. 


\subsection{ANNUAL REPORTING}

An annual report will be prepared that will provide the observations and describe modifications and/or repairs made to the cover and cover area. The annual report will be prepared following the second inspection of each year that post-closure monitoring is conducted. The annual reports will include the following information:

- Discussion of observations.

- Inspection checklist (see Appendix D for example inspection form) and maintenance record.

- Conclusions and recommendations.

A copy of each annual report will be submitted to the NDEP.

\subsection{DURATION}

The biannual inspections will be performed for five years after the planting of the vegetative covers, and will be documented on inspection forms.

Completion of post-closure monitoring of CAU 426 may be proposed after two consecutive years of visual inspections have not indicated the need to revegitate or provide maintenance to the vegetative covers. Completion of post-closure monitoring may be proposed within five years after the original revegetation of the site and include the-removal of the fence since the plants will have attained a maturity to not be significantly affected by the grazing of wild horses. 


\subsection{CONCLUSSIONS AND RECOMMENDATIONS}

\subsection{CONCLUSIONS}

The following conclusions are made based upon the completed site closure activities and information provided in this report:

- An engineered cover was constructed over the area of the trenches.

- Compaction results exceeded the minimum requirement of 80 percent of the maximum density.

- The vegetative cover and area within the fence was planted with seeds from native shallow rooted plants/grasses.

- A fence with signs was, installed on the perimeter of the site to allow the plants/grasses to establish and prevent unauthorized excavation into the engineered cover.

- Closure activities have been coordinated with the USAF.

- The Use Restriction Form was transmitted to the USAF on August 6, 1998 for recordation. After recordation, the USAF will provide the DOE/NV and NDEP with a confirmation of the recordation.

- The field closure activities conducted at the site were completed in accordance to the approved CAP (DOE, 1997b).

\subsection{RECOMMENDATIONS}

The DOE/NV provides the following recommendations since the proposed closure activities were completed at the site:

- A Notice of Completion be provided by the NDEP to DOE/NV for the closure of CAU 426 (Cactus Spring Trenches [CAS Number RG-23-001-RGCS]).

- CAU 426 be moved from Appendix III to Appendix IV of the FFACO.

DOEINV will continue to perform post-closure monitoring of the site as indicated in Section 5.0 of this CR. 


\subsection{REFERENCES}

\section{American Society for Testing and Materials, see ASTM}

ASTM, 1997a. Method D 1557-91: Test Method for Laboratory Compaction Characteristics of Soil Using Modified Effort, 1997Annual Book of ASTM Standards, Volume 04.08, Soil and Rock (I): D 420 - D 4914.

ASTM, 1997b. Method D 422-90: Standard Test Method for Particle-Size Analysis of Soils, and Method D 1140-92: Standard Test Method for Amount of Material in Soils Finer Than the No. 200 Sieve, 1997 Annual Book of ASTM Standards, Volume 04.08, Soil and Rock (I): D 420 - D 4914.

ASTM, 1997c. Method D 2922-96: Standard Test Methods for Density of Soil and SoilAggregate in Place by Nuclear Methods (Shallow Depth), 1997 Annual Book of ASTM Standards, Volume 04.08, Soil and Rock (I): D 420 - D 4914.

\section{U.S. Department of Energy, see DOE}

DOE, 1996. Corrective Action Investigation.Plan: Cactus Spring Waste Trenches, Rev. 0, May 1996, DOE/NV-429.

DOE, 1997a. Corrective Action Decision Document For the Cactus Spring Waste Trenches, Rev. 1, July 1997, DOE/NV-474 UC-700.

DOE, 1997b. Corrective Action Plan for Corrective Action Unit 426, Cactus Spring Waste Trenches, Tonopah Test Range, September 1997, DOE/NV-11718-153 UC-702.

\section{U.S. Environmental Protection Agency, see EPA}

EPA, 1996. Region IX Preliminary Remediation Goals (PRGs), San Francisco, CA. .

\section{Nevada Division of Environmental Protection, see NDEP}

NDEP, 1996. The State of Nevada Department of Conservation and Natural Resources, Division of Environmental Protection and the U.S. Department of Energy and the U. S. Department of Defense Federal Facility Compliance Order And Agreement.

NDEP, 1997a. Letter from Karen K. Beckley. to Stephen A. Mellington, RE: Corrective Action Plan for CAU No. 426. Cactus Spring Waste Trenches, Tonopah Test Range (DRAFT), August 1997, August 21, 1997.

NDEP, 1997b. Letter from Paul J. Liebendorfer to Stephen A. Mellington, $\underline{\mathrm{RE}}$ : Corrective Action Plan for Corrective Action Unit 426, Cactus Spring Waste Trenches, TTR, September 29, 1997. 
Date: August 12, 1998

\section{APPENDIX A}

\section{AS-BUILT ENGINEERING DRAWINGS}




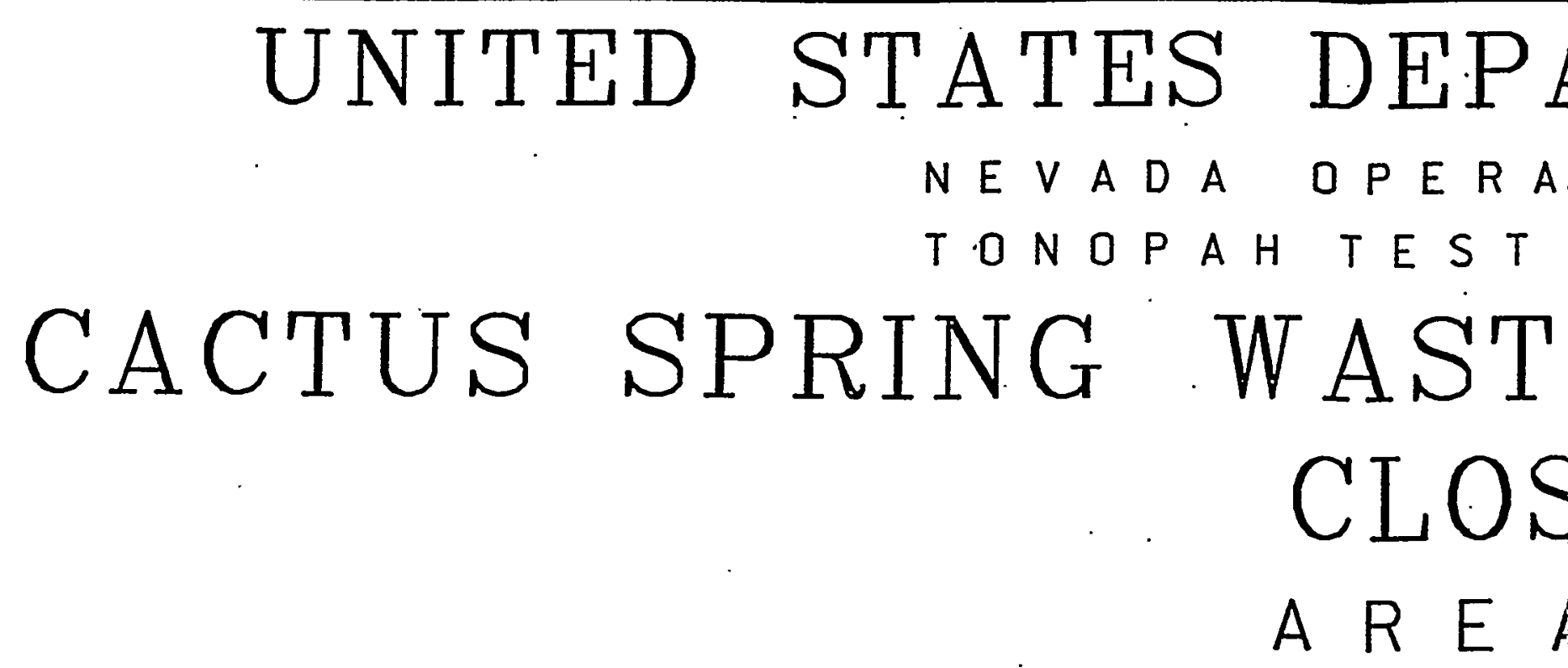

\section{INDEX}

\section{DRATIKG NUMBER DRATIKG TITLB}

TITLE

JS-0S2-133-T2 REV , TITLE SHEET

CIVIL

J5-052-133-CA REV I JS-052-133-CS REV :

JS-052-133-CE REV
VICINIT mos SITE \& CRADING PLNA secrions
STANDARD NUUBBR

STD $\mathrm{rt}$

STO C100
STD C101

sions

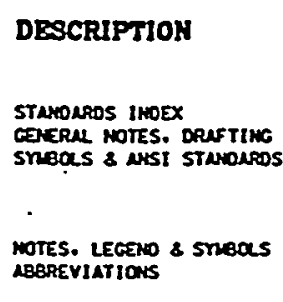

ABEREVIATIONS
SCOPE OF TORK

THIS PPOUECT SHMLL CONSIST OF PLACIMG MUTIVE FILL TO COOSE THE CACTIS

SPRIHO WASTE TREMOAES. WOPX WILL MLSO THCLUE PEVVEGETATIOH OF THE SITE.

WORX SHULL BE PERFCRAEO IH ACCOPONHCE WITH DOENNY STO SPECIFICATIONS

OATEO DECENEER 1994.

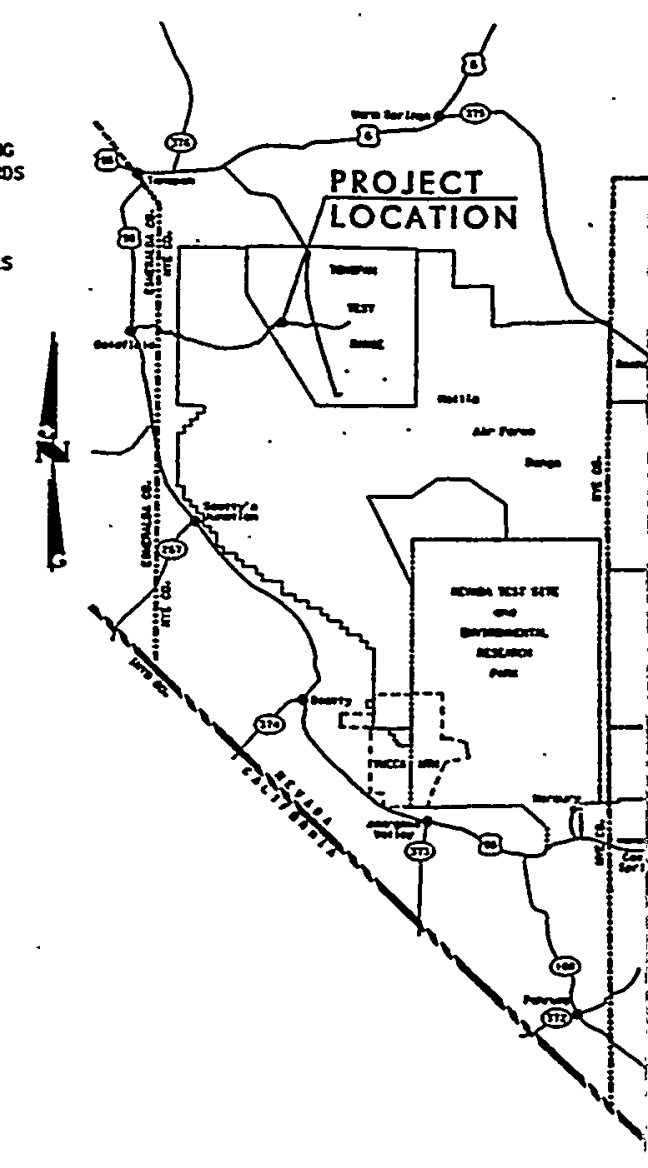




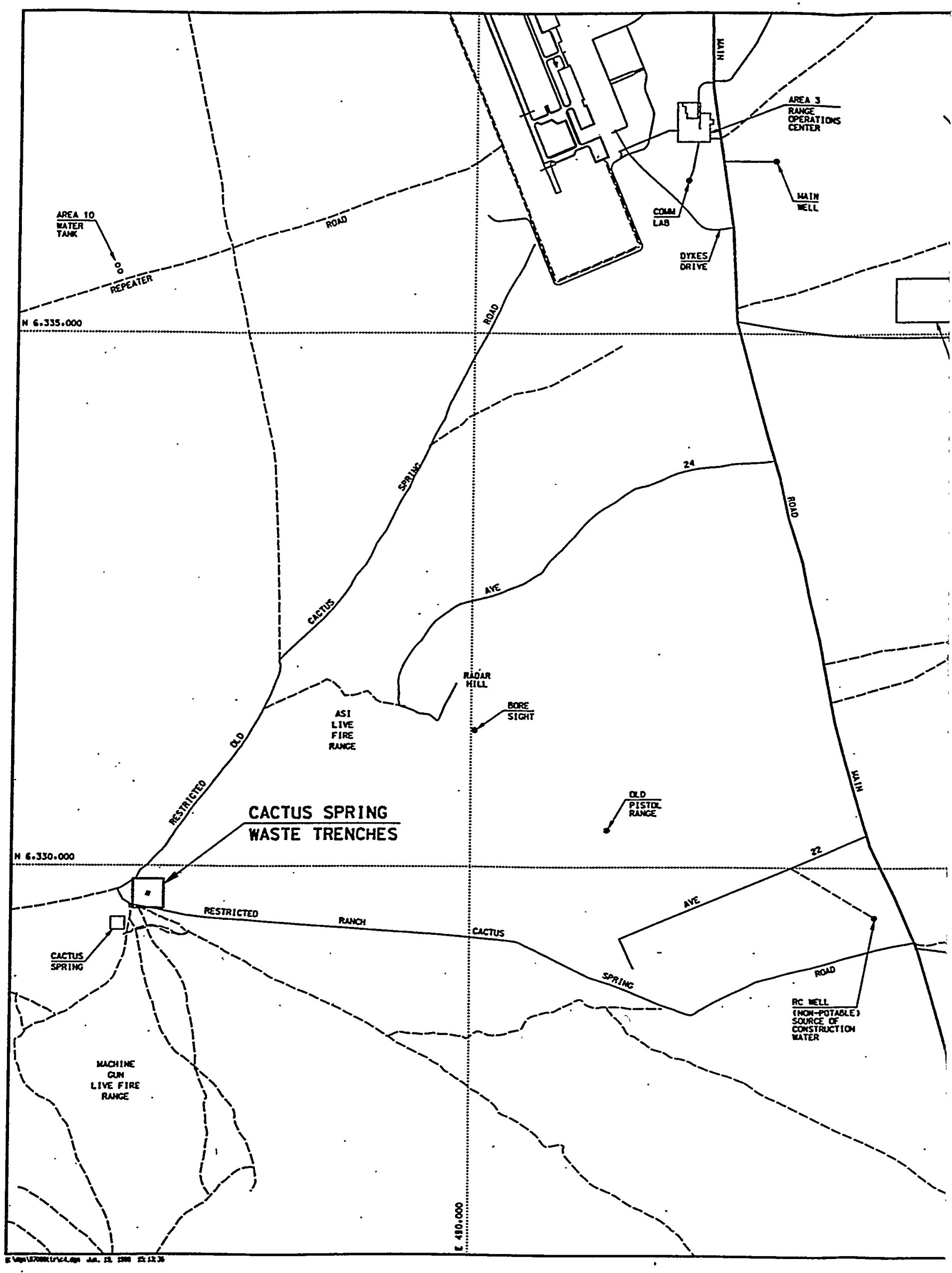




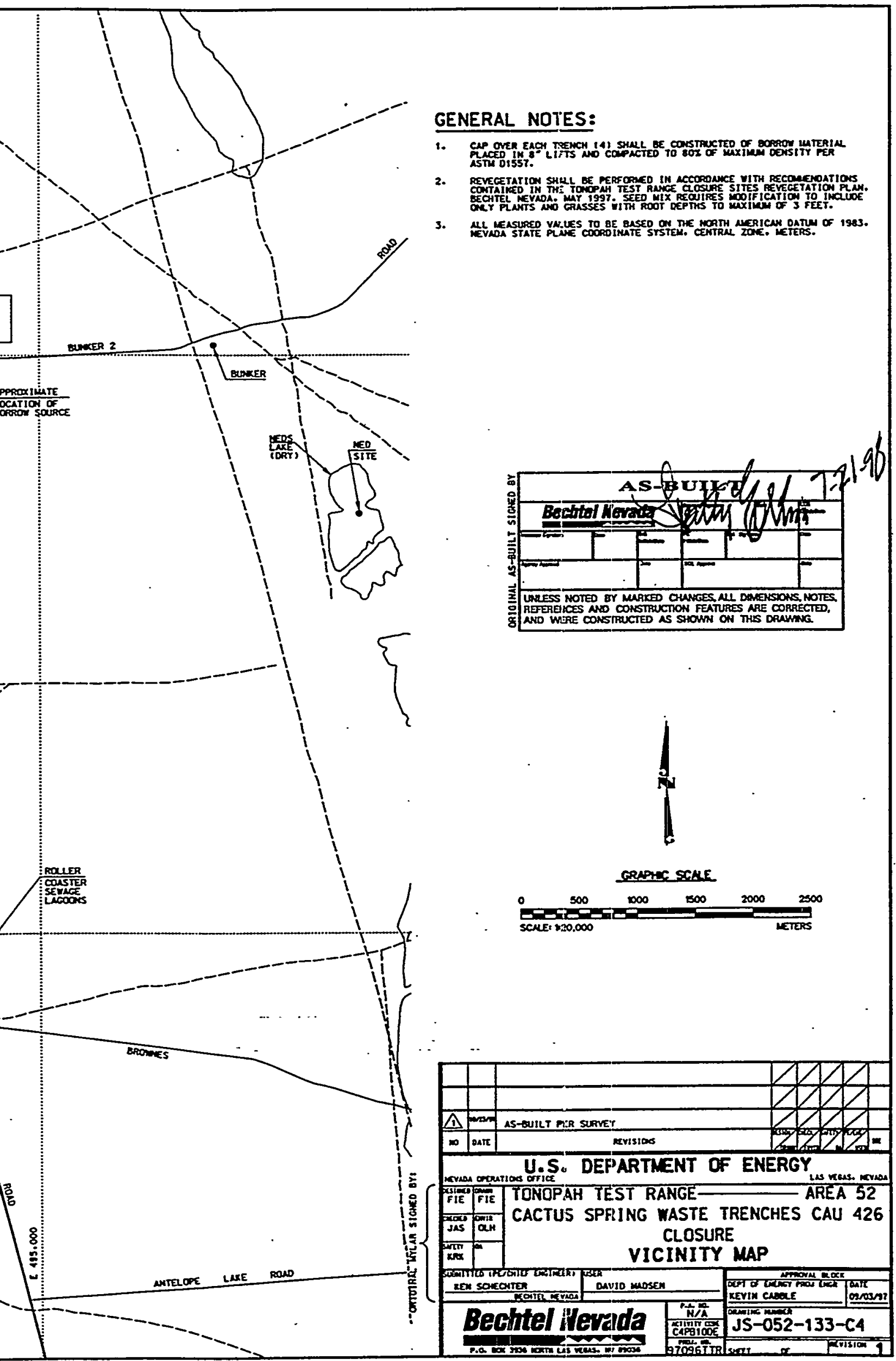




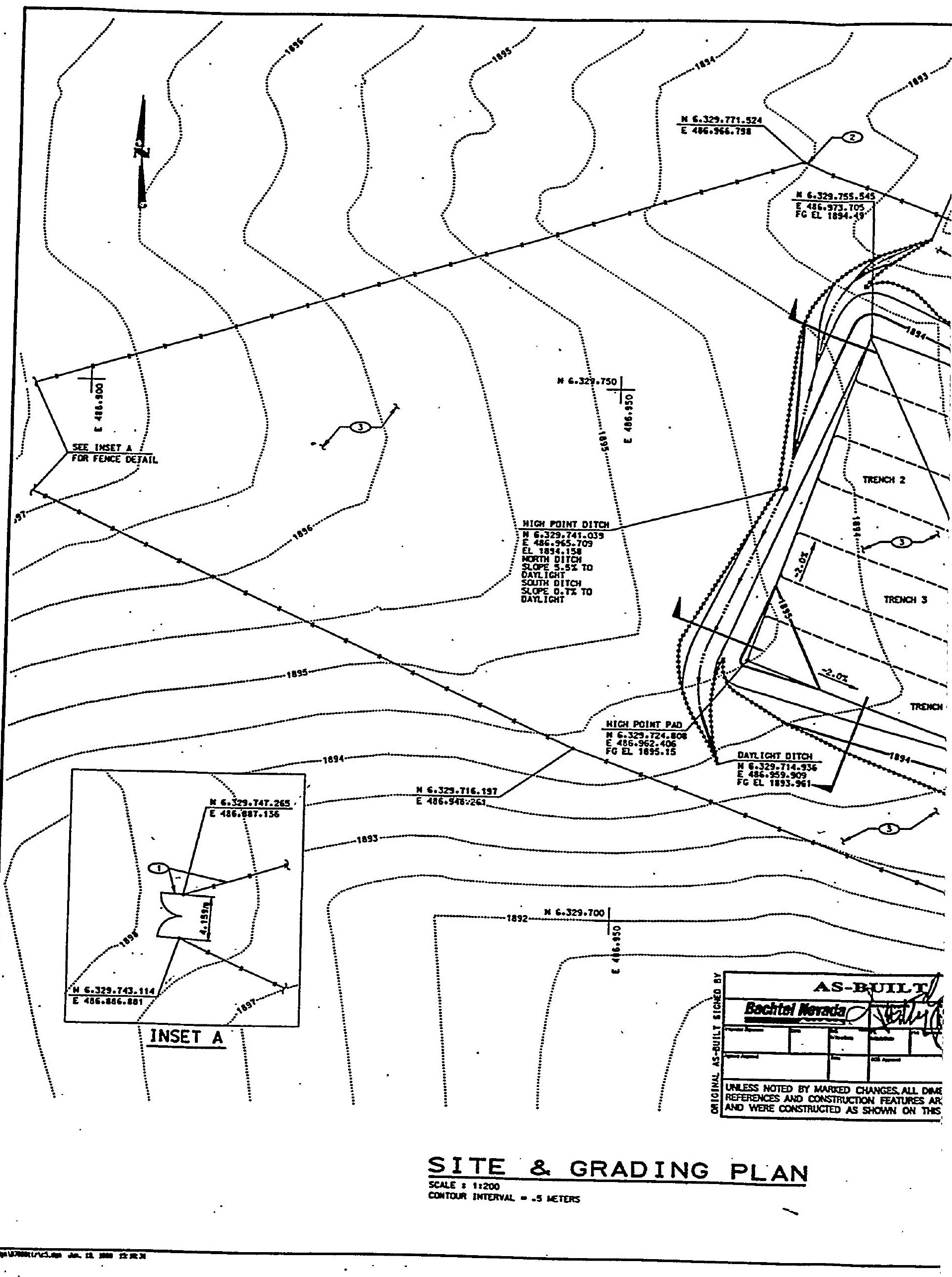




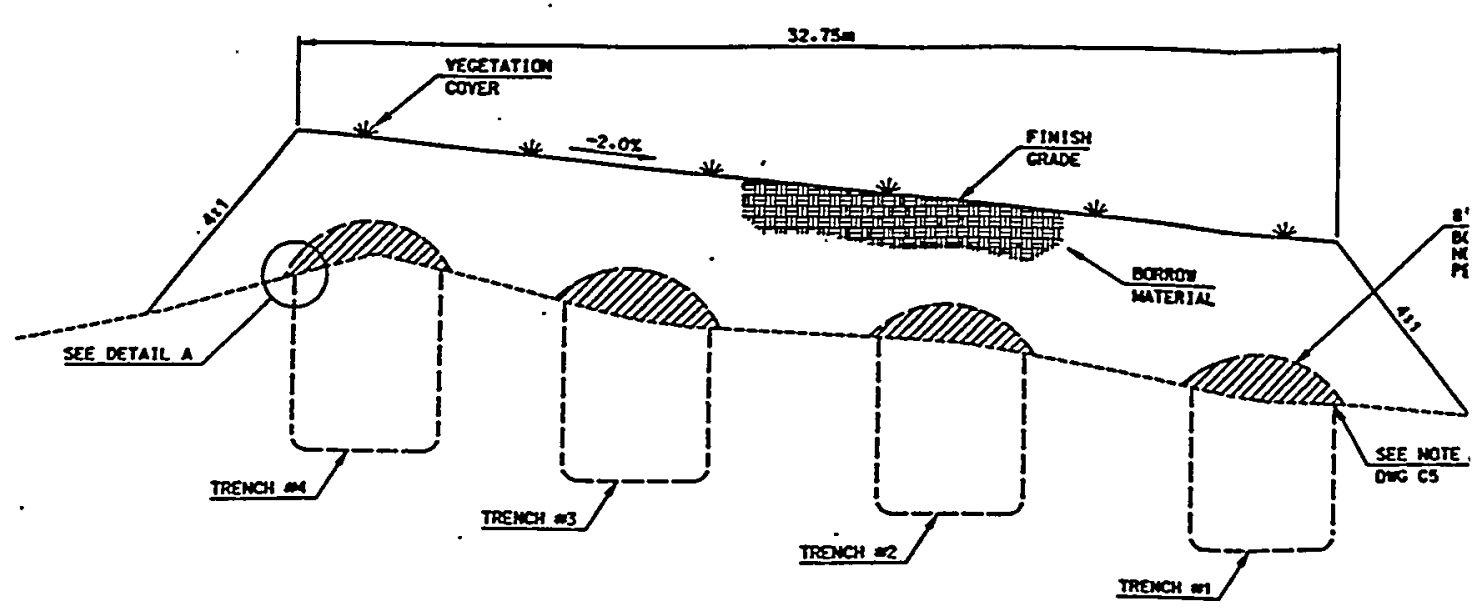

SECT I ON not ro scue

(A)

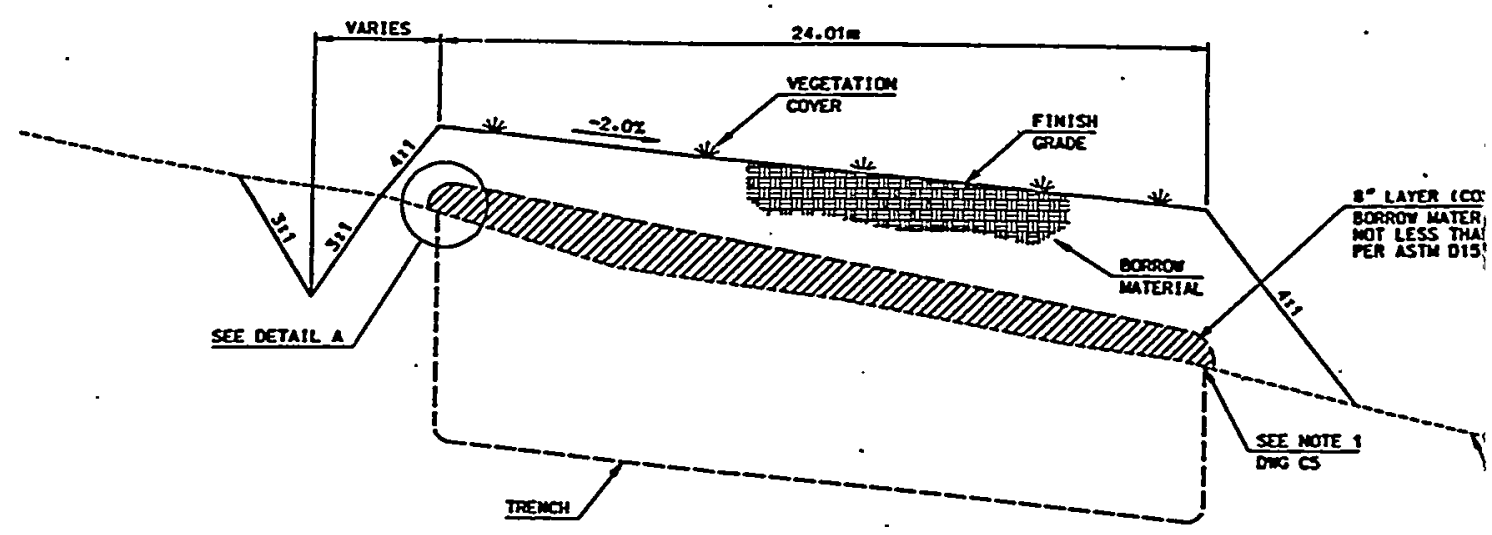

SECTION not To sene

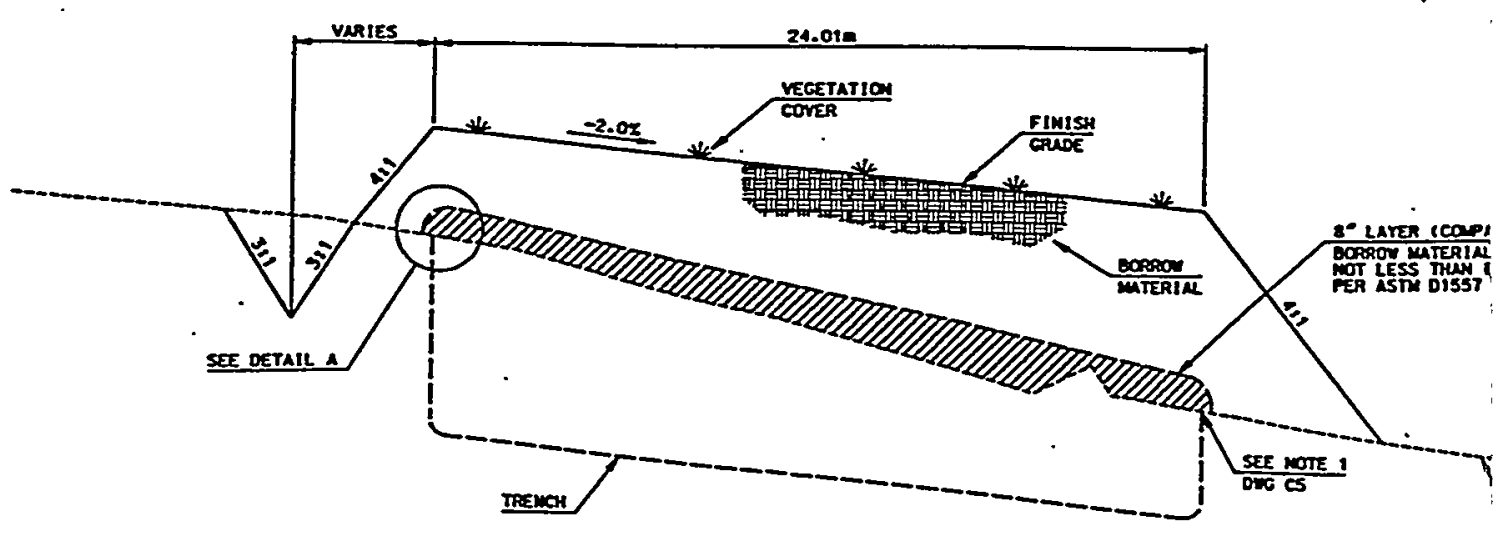

SECTION Nor ro sene

c) 
CR - CAU No. 426

Section: Appendix B

Cactus Spring Tresches

Revision: 0

Date: August 12, 1998

\section{APPENDIX B}

\section{USE RESTRICTION DOCUMENTATION}


Date: August 12, 1998

\section{USAF ACKNOWLEDGMENT LETTER}




\section{DEPARTMENT OF THE AIR FORCE \\ HEADQUARTERS 99TH AIR BASE WING (ACC) \\ NELLIS AIR FORCE BASE, NEVADA}

Colonel Michael F. Fukey

JUL 151998

Director, Environmental Management

4349 Duffer Dr., Ste. 1601

Nellis AFB NV 89191-7007

Ms. Runore C. Wycoff,

Director, Environmental Restoration Division

DOE Nevada Operations Office

P.O. Box 98518

Las Vegas NV 89193-8518

\section{ACKNOWLEDGEMENT OF CORRECTIVE ACTION UNIT (CAU) 426}

Nellis Air Force Base (Nellis) has reviewed the U. S. Department of Energy's (DOE) Corrective Action Decision Document for Corrective Action Unit (CAU) 426. Nellis has the right to use this land for military purposes under Public Law 99-606, as amended, and Public $\cdot$ Land Order 7131.

Nellis can only impose restrictions on its use of the land while under its control. For the above referenced site, these self-imposed restrictions by Nellis on its use of this section of NAFR (hereafter "use restrictions") will be placed in the Geographic Information System (GIS) for NAFR. The Range Management Office (RMO) at Nellis will administer use restrictions to ensure that there are institutional controls on users of the NAFR, ensuring that they are aware of these restrictions located in the GIS, which should assist the DOE in working with the state regulators on Corrective Active Units. If RMO determines that a proposed mission use would not comport with existing use restrictions or that there is a proposed transfer/relinquishment of all or part of the NAFR, it will notify DOE of the proposed transfer/relinquishment. Then DOE must contact the regulators or transferee/returnee to address and resolve cleanup issues associated with the proposed use or transfer/relinquishment.

If RMO needs to modify its use restrictions thereby causing additional cleanup requirements to meet the proposed land-use scenarios, then DOE will clean the restricted land up to the level to meet the proposed land-use scenarios in an expeditious manner so that RMO may amend the use restrictions. 
Also, Nellis and DOE are negotiating a Memorandum of Understanding that will address DOE's future obligations to clean up any of its contaminated areas.

Please contact me at $652-6828^{\circ}$ if you have any questions.

\author{
Sincerely

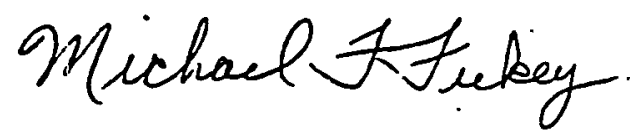 \\ MICHAEL F. FUKEY, Colonel, USAF
}

cc:

HQAWC RMO/RML

HQ AWFC/JAV 
Cactus Spring Trenches

Revision: 0

Date: August 12, 1998

CAU USE RESTRICTION FORM 


\section{CAU Use Restriction Information}

CAU Number/Description: CAU 426 Cactus Spring Waste Trenches. Tonopah Test Range Nevada in..

Applicable CAS Numbers/Descriptions: CAS RG-23-001-RGCS (Waste Trenches)

Contact (organization/project):DOENV Industrial Sites Project Manager

Surveyed Area (UTMs): N6.329.756.597 E486.970.842: N6.329.745.20 E486.998.971:

N6.322.725.870 E486.959.543:N6.329.714.760 E486.989.737.

Survey Date _10/23/97 Survey Method (GPS, etc.)__ GPS

Datum_NAD 83

\section{Use Restrictions}

The future use of any land related to this Corrective Action Unit (CAU), as described by the above surveyed location, is restricted from any DOE or Air Force activity that may alter or modify the containment control as approved by the state and identified in the CAU Closure Report or other CAU documentation unless appropriate concurrence is obtained in advance.

Comments: See the Closure Report for additional information on the condition of the site(s) and any monitoring and/or inspection requirements.

Submitted By:

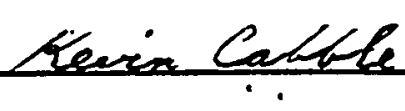

Date:

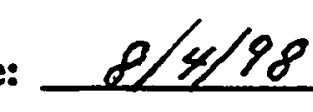

Attachments: Survey Map 


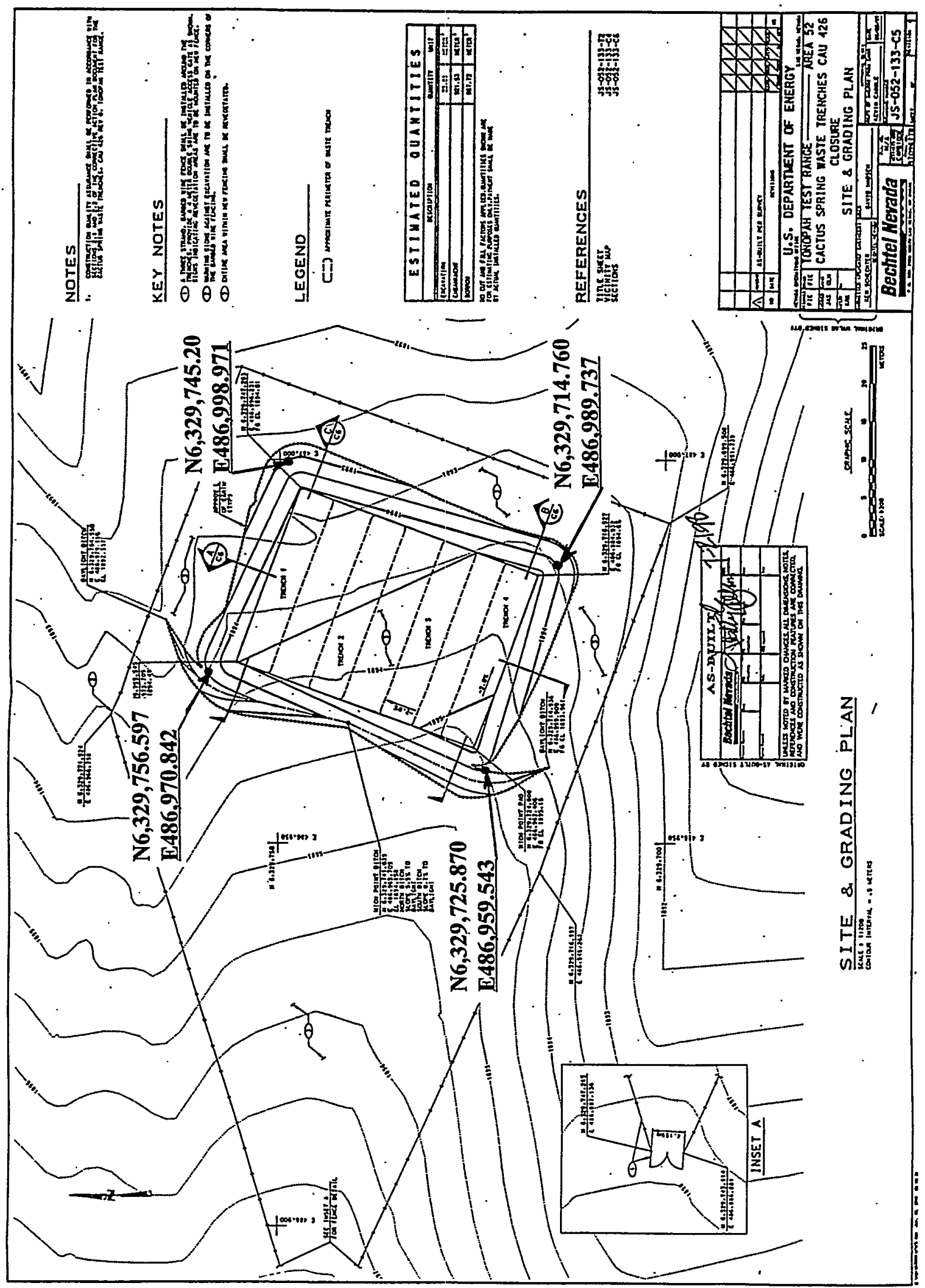


Date: August 12, 1998

\section{APPENDIX C}

\section{GEOTECHNICAL TEST RESULTS}


PROOCTORTEST

ASTM D. 1557 -91

$\mathrm{METHOD}$
BECTICI NIEV $X D /$

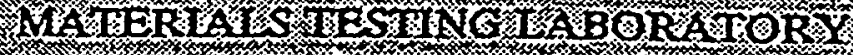

D $10 . \mathrm{BO} \times 0.0521$

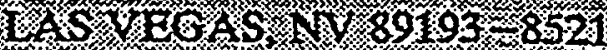

CHARGE \#, CARBIODE

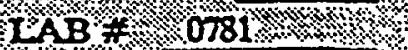

DATE $0814 \% 97$ :

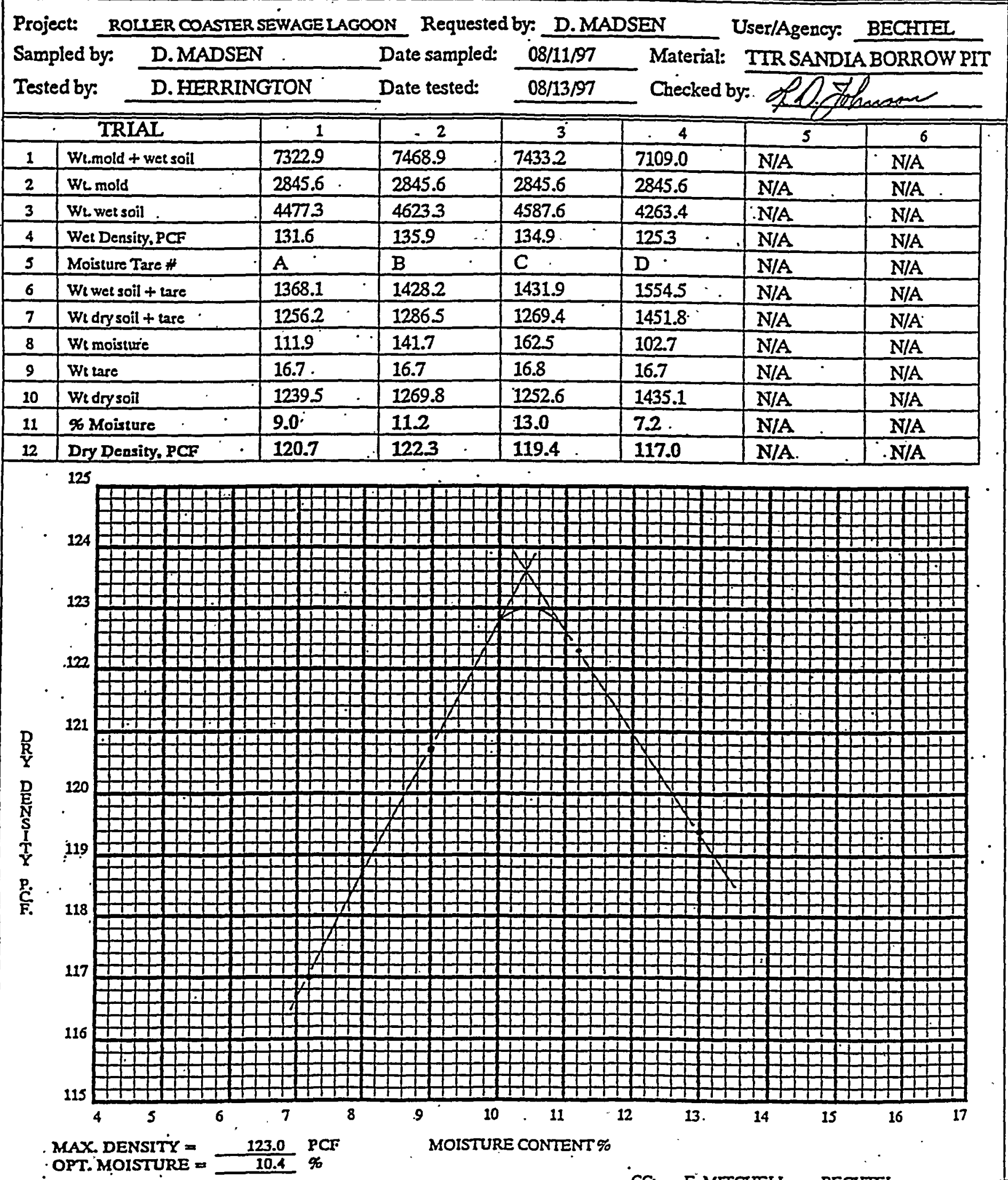

NO SPECTFCATIONS: INFORMATION ONLY

Equipment used: PM 16. PTL W1256. Cal. date: 06/05/97. Cal. due: 06/05/98

D.MADSEN BECFTEL MTLBECHTELFILES 


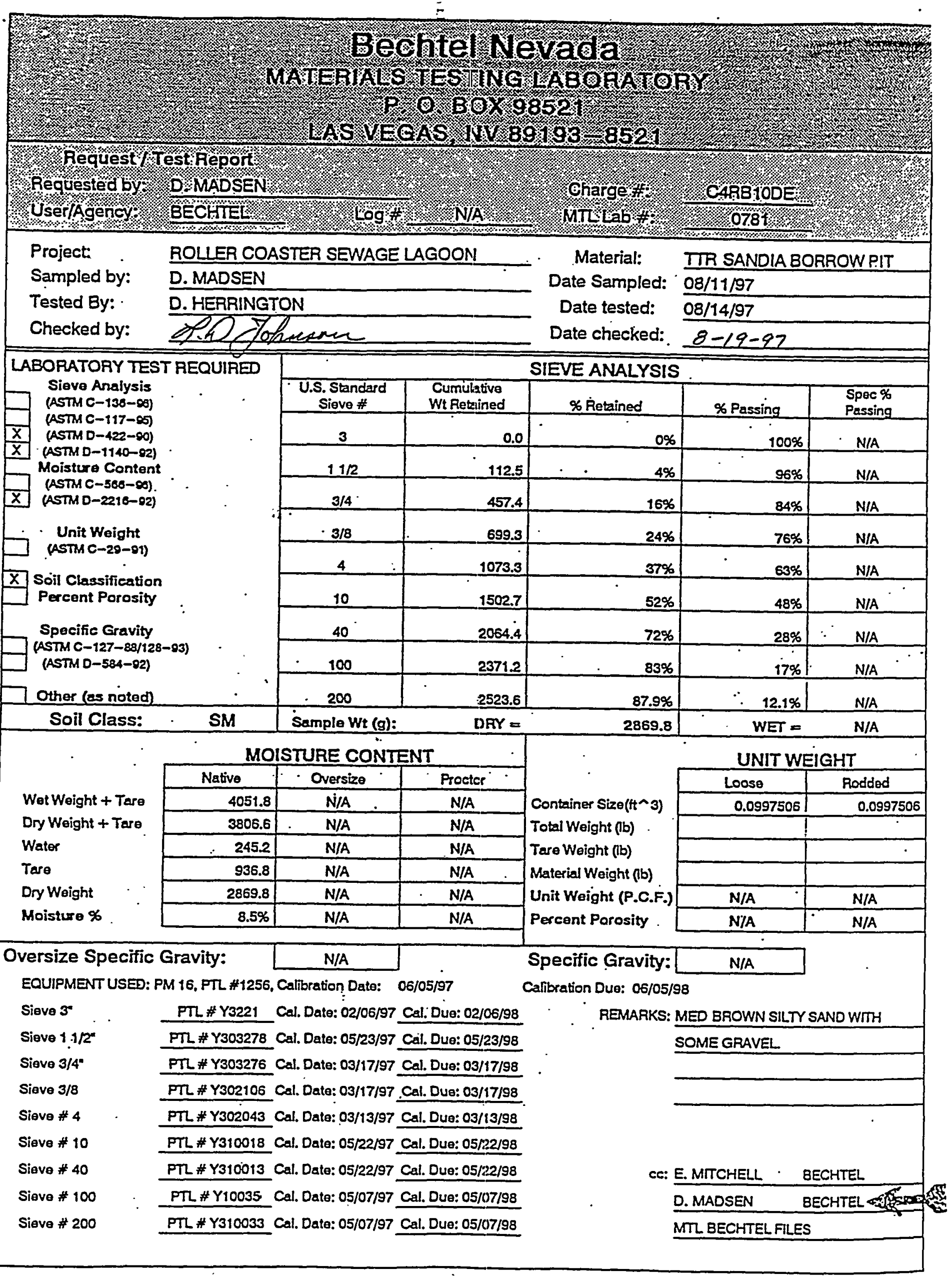


SEP 2.21587

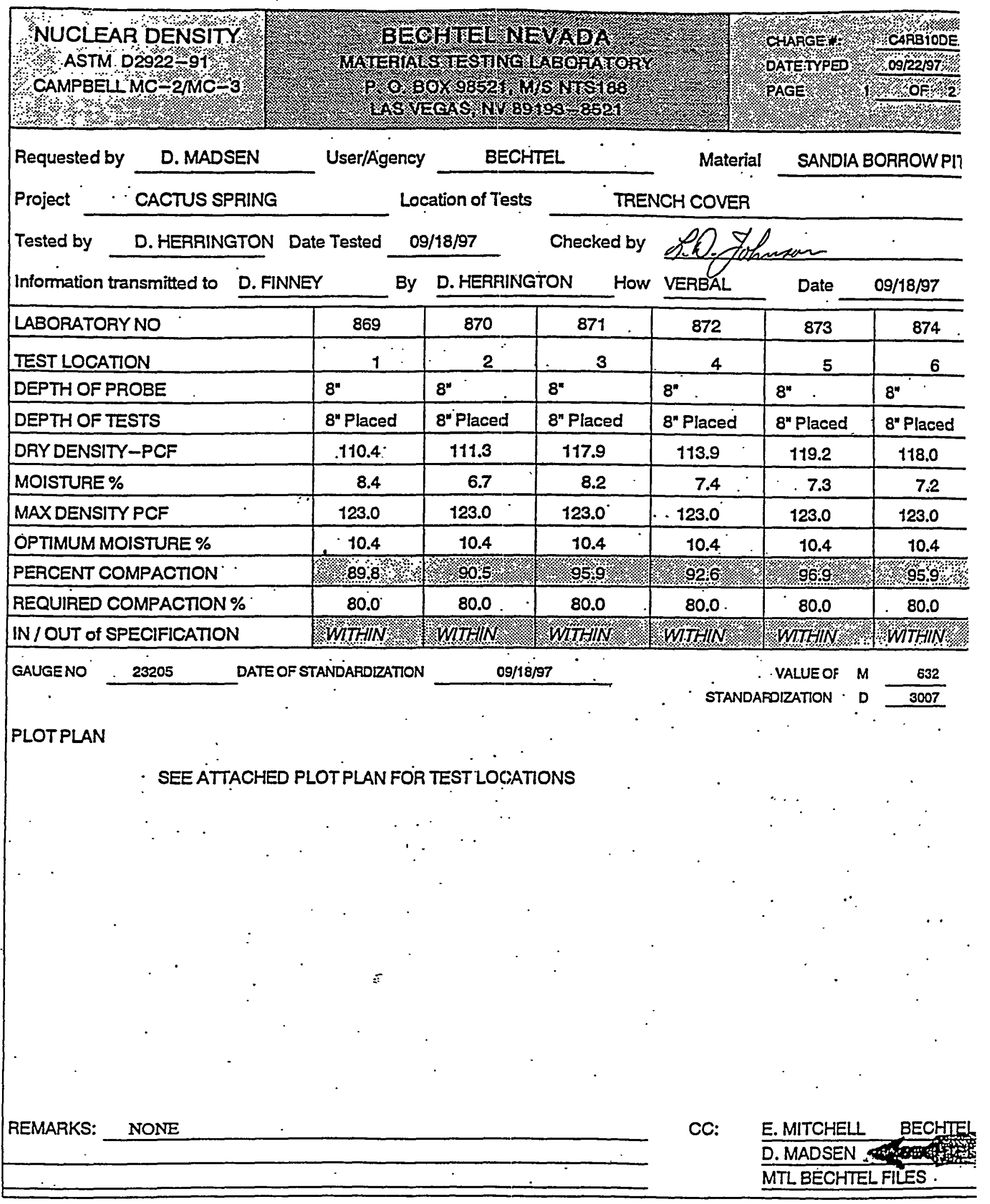




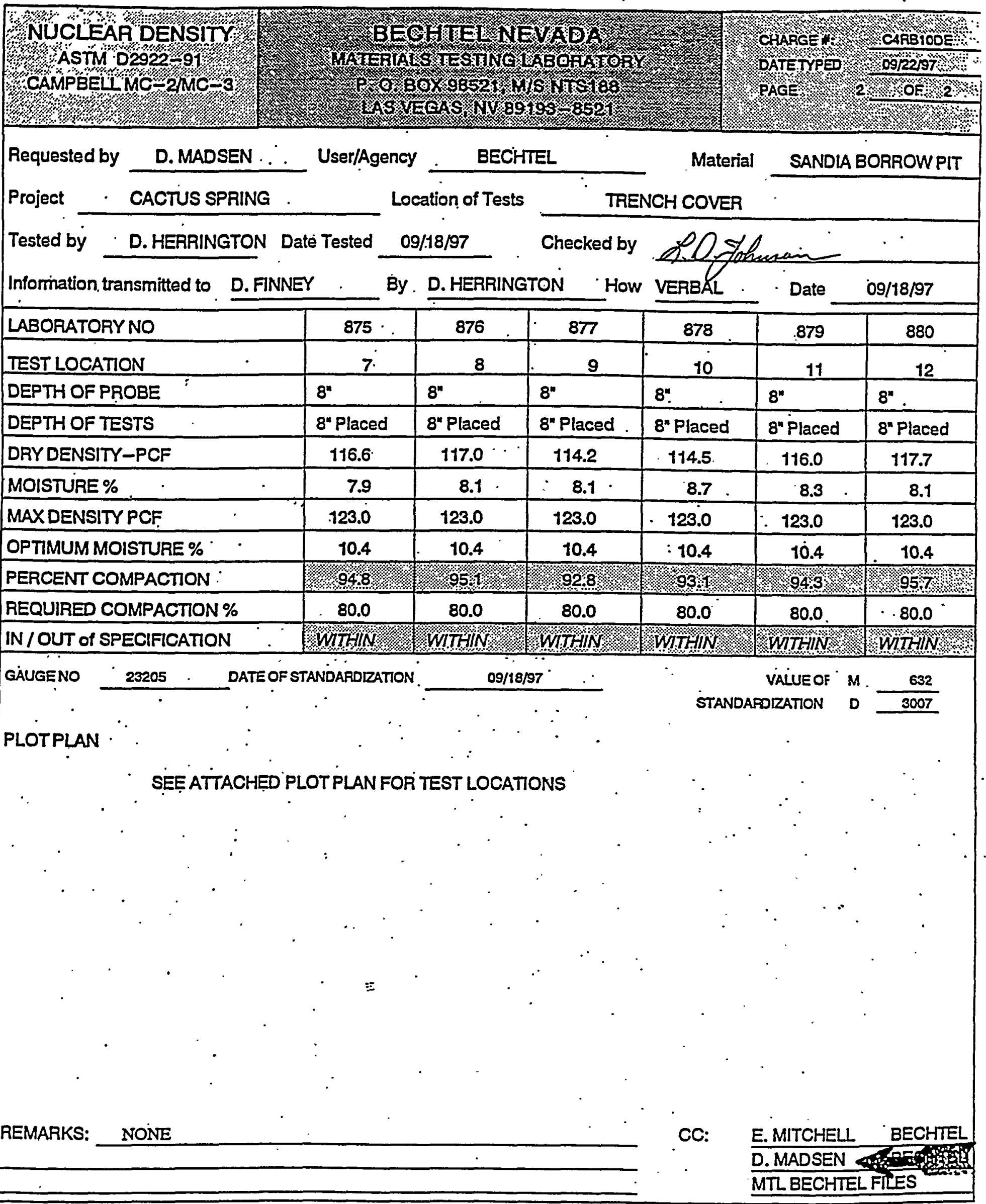




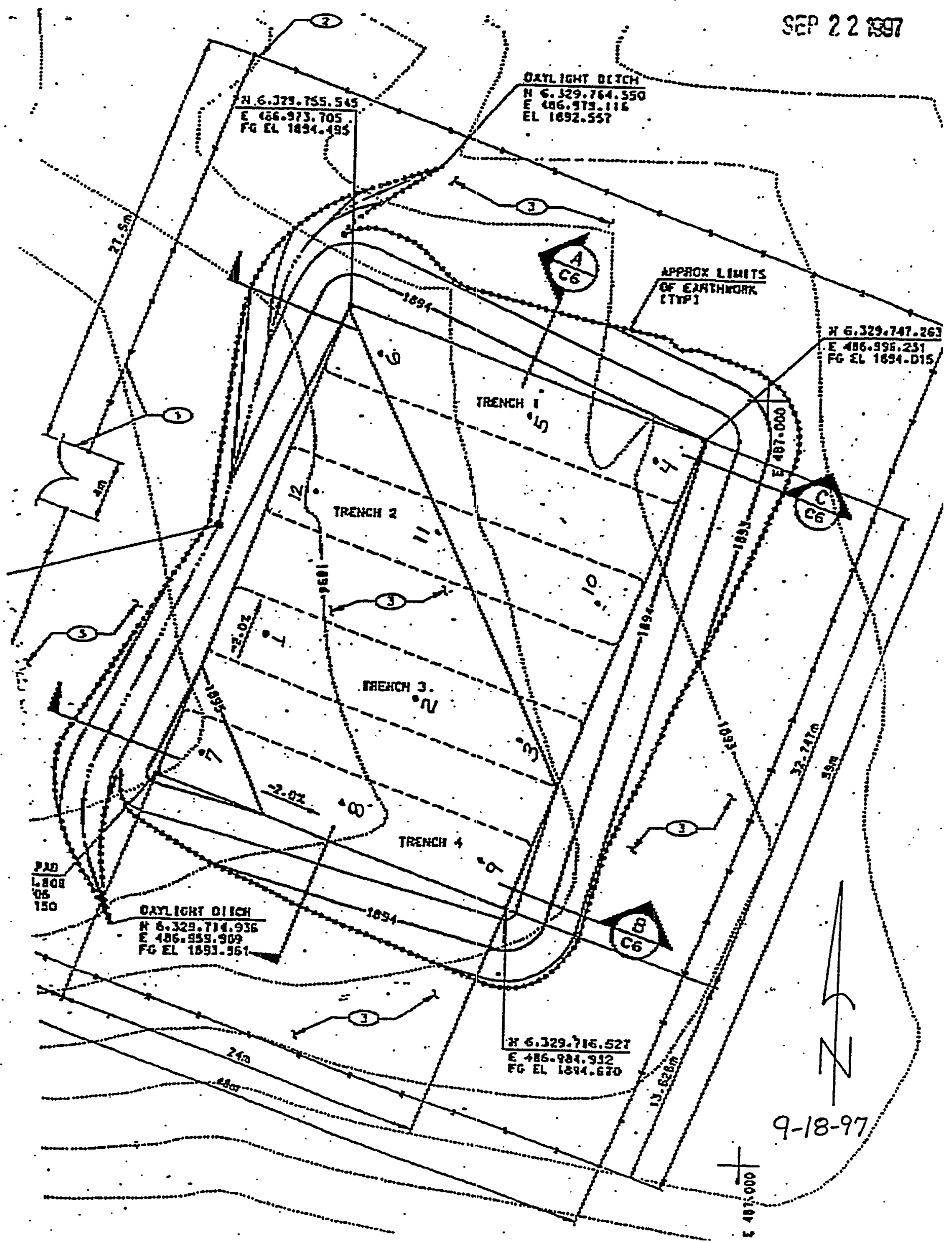




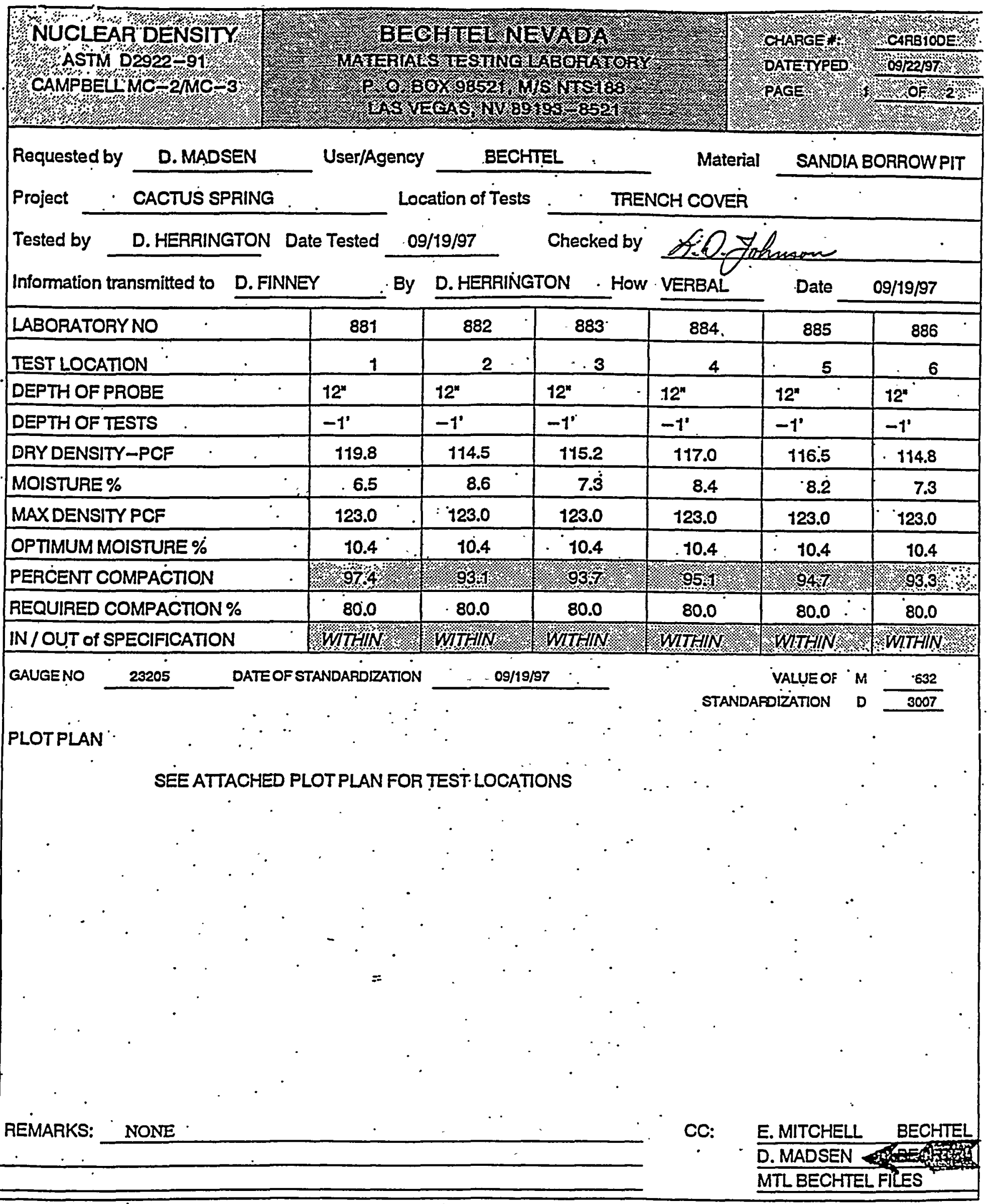




\section{SEP 22897}

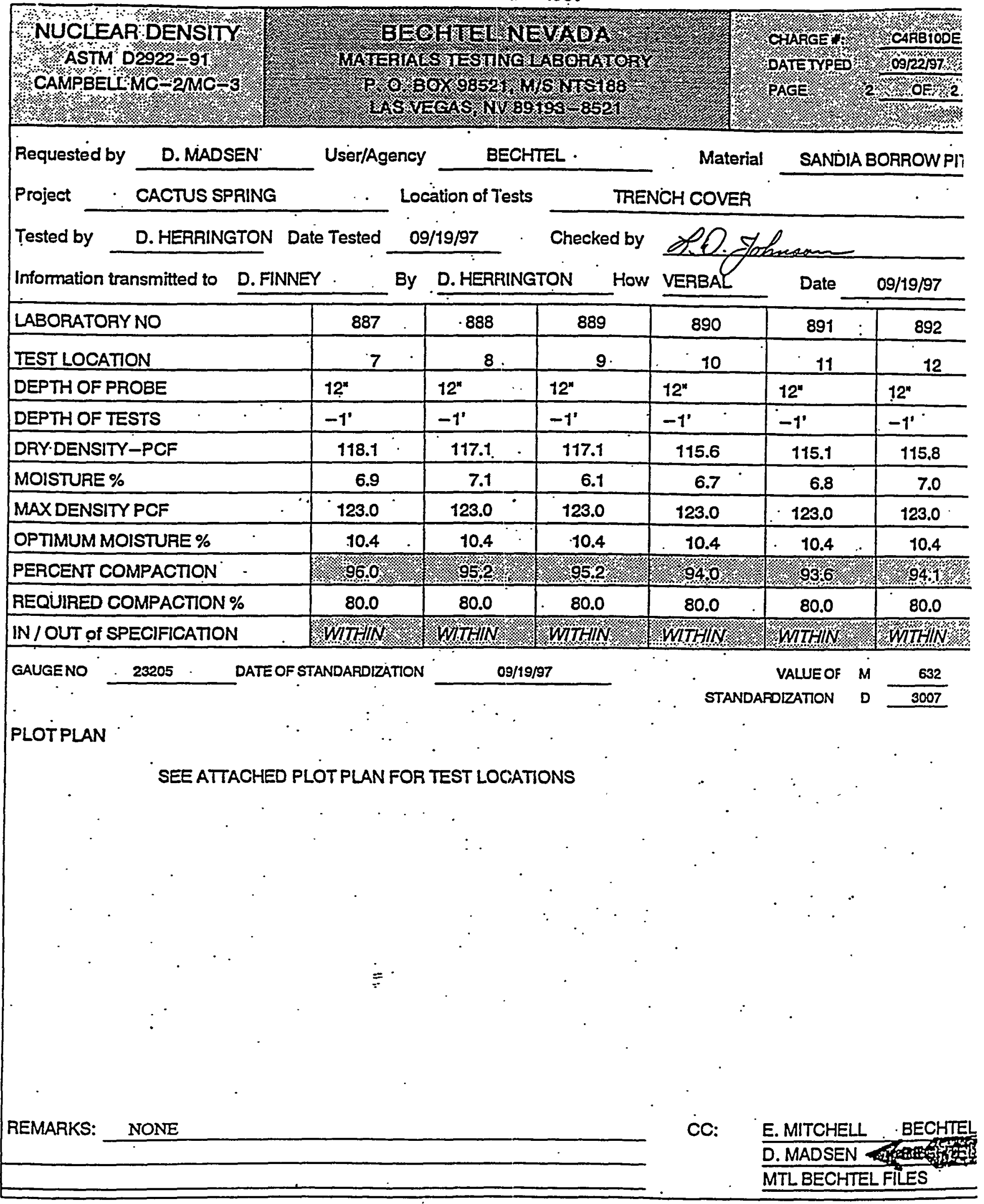




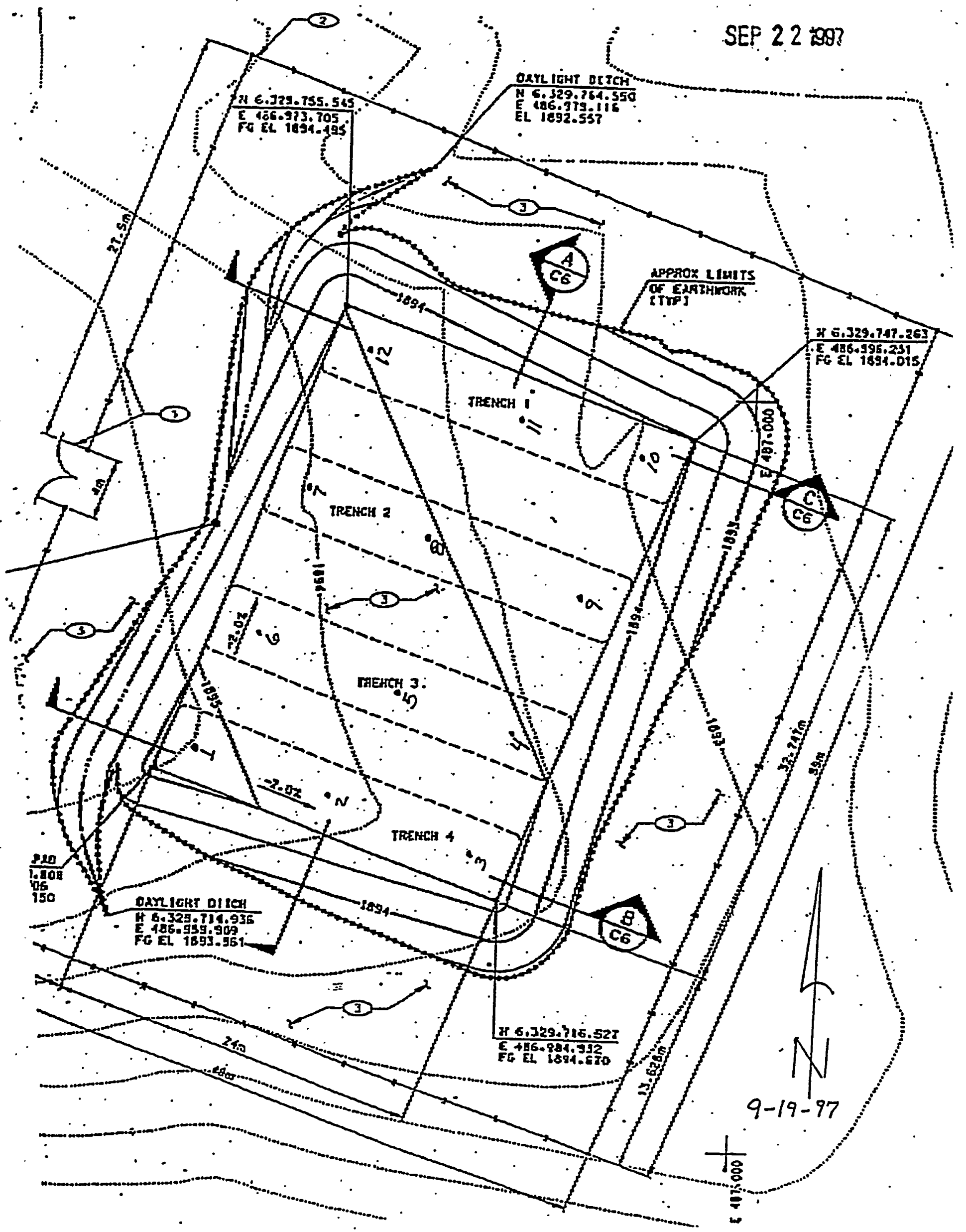




\section{APPENDIX D}

\section{POST-CLOSURE MONITORING CHECKLIST}


CACTUS SPRING WASTE TRENCHES, POST-CLOSURE MONITORING CHECKLIST

\begin{tabular}{||l|l||}
\hline Date of Last Inspection: & Reason for Last Inspection: \\
\hline Responsible Agency: & Project Manager: \\
\hline Inspection Date: & \\
\hline Inspector (name, title, organization): & \\
\hline Assistant inspector (name, title, organization): \\
\hline
\end{tabular}

A. GENERAL INSTRUCTIONS

1. All checklist items must be completed and detailed comments made to document the results of the site inspection. The completed checklist is part of the field record of the inspection. Additional pages should be used as necessary to ensure that a complete record is made. Attach the additional pages and number all pages upon completion of the inspection.

3. Any checklist line item marked by an inspector in a SHADED BOX, must be fully explained or an appropriate reference to previous reports provided. The purpose of this requirement is to provide a written explanation of inspector observations and the inspector's rationale for conclusions and recommendations. Explanations are to be placed on additional attachments and cross-referenced appropriately. Explanations, in addition to narrative, will take the form of sketches, measurements, annotated site maps.

4. The site inspection is a walking inspection of the entire site including the perimeter and sufficient transects to be able to inspect the entire surface and all features specifically described in this checklist.

5. A standard set of color $35 \mathrm{~mm}$ photographs (or equivalent) is required. In addition, all anomalous features or new features (such as changes in adjacent area land use) are to be photographed. A photo log entry will be made for each photograph taken.

6. This unit will be inspected biannually with formal reporting to the Nevada Division of Environmental Protection to be.done annually. The annual report will include an executive summary, this inspection checklist with field notes and photo log attached, and recommendations and conclusions.

\begin{tabular}{||l|c|c|c||}
\hline B. PREPARATION To be completed prior to site visit) & YES & NO & EXPLANATION \\
\hline 1. Site as-built plans and site base map reviewed. & & & \\
\hline 2. Previous inspection reports reviewed. & & & \\
a. Were anomalies or trends detected on previous inspections?. & $\ddots$ & & \\
b. Was maintenance performed? & & & \\
\hline 3. Site maintenance and repair records reviewed. & & & \\
a. Has site repair resulted in a change from as-built conditions? & & & \\
b. Are revised as-builts available that reflect repair changes? & & & \\
\hline C. STTE INSPECTION (To be completed during inspection) & YES & NO & EXPLANATION \\
\hline
\end{tabular}

1. Adjacent off-site features within watershed areas.

a. Have there been any changes in use of adjacent area?

b. Are there any new roads or trails?

c. Has there been a change in the position of nearby washes?

d. Has there been lateral excursion or erosion/deposition of nearby washes?

e. Are there new drainage channels?

f. Change in surrounding vegetation?

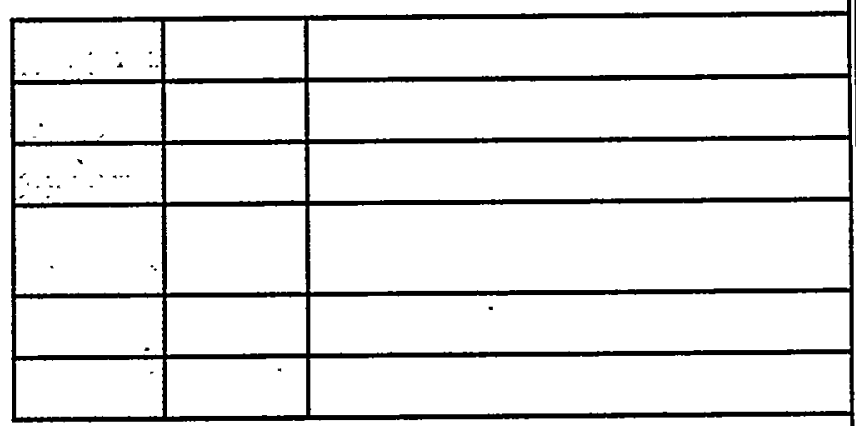

2. Security fence, signs.

a. Displacement of fences, site markers, boundary markers, or monuments?

b. Have any signs been damaged or removed? (Number of signs replaced:

)

c. Were gates locked?

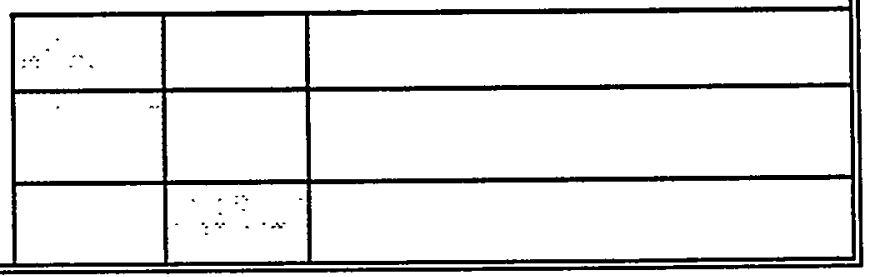




\section{CACTUS SPRING WASTE TRENCHES, POST-CLOSUFIE MONITORING CHECKLIST}

3. Waste Unit cover.

a. Is there evidence of settling?

b. Is there cracking?

c. Is there evidence of erosion around the cap (wind or water)?

d. Is there evidence of animal burrowing?

e. Have the site markers been disturbed by man or natural processes?

f. Do natural processes threaten to integrity of any cover or site marker?

g. Other?

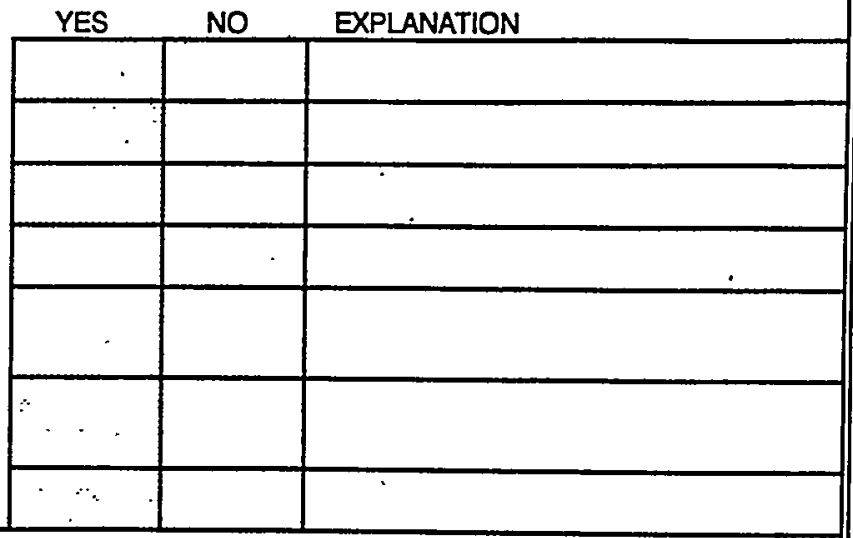

4. Vegetative cover.

a. Is perimeter fence or mesh fencing damaged?

b. Is there evidence of horses or rabbits on site?

c. Is organic mulch adequate to prevent erosion?

d. Are weedy annual plants present? If yes, are they a problem?

e. Are seeded plant species found on site?

t. Is there evidence of plant mortality?

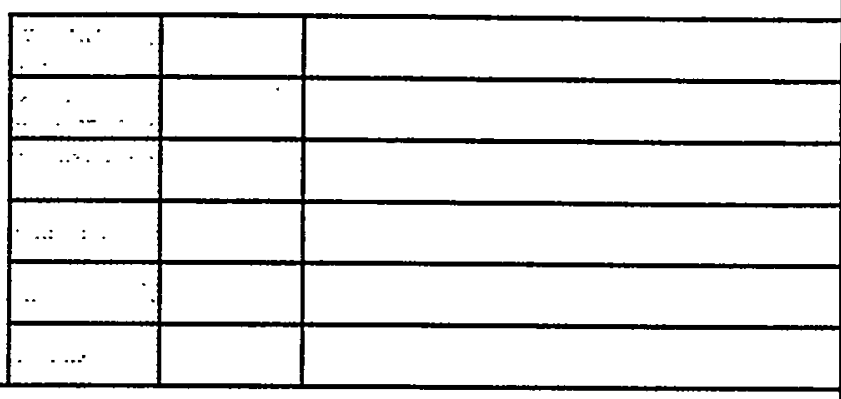

5. Photo Documentation
a. Has a photo log been prepared?
c. Number of photos exposed (

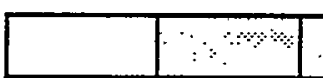

1

\section{FIELD CONCLUSIONS}

1. Is there an imminent hazard to the integrity of the unit? (immediate report required)

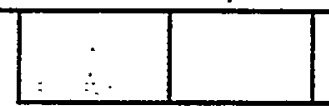

Person/Agency to whom report made:

2. Are more frequent inspections required?

3. Are existing maintenance/repair actions satisfactory?

4. Is other maintenance/repair necessary?

5. Is current status/condition of vegetative cover satisfactory?

6. Rationale for field conclusions:

\section{-E. CERTIFICATION}

I have conducted an inspection of the Cactus Spring Waste Trenches, CAU 426, at the TTR in accordance with the Post-Closure Monitoring Plan (see Closure Report) as recorded on this checklist, attached sheets, field notes, photo logs, and photographs. 
CR - CAU No. 426

Section: Distribution

Cactus Spring Treiches

Revision: 0

Date: August 12, 1998

\section{DISTRIBUTION LIST}




\section{DISTRIBUTION LIST}

\section{Controlled Copies}

Bureau of Federal Facilities

Division of Environmental Protection

333 W. Nye Lane, Room 13B

Carson City, NV 89706-0866

P. J. Liebendorfer

2

K. K. Beckley

U.S. Department of Energy, Nevada Operations Office

P. O. Box 98518,505

Las Vegas, NV 89193-8518

S. D. Lawrence

U.S. Department of Energy, Nevada Operations Office

P. O. Box 98518,505

Las Vegas, NV 89193-8518

Janet L. Appenzeller-Wing

Kevin J. Cabble

Public Reading Room

Technical Information Resource Center

U. S. Department of Energy, Office of Scientific and Technical Information

P. O. Box 62

Oak Ridge, TN 37831

\section{Bechtel Nevada}

P. O. Box 98521, M/S NLV008

Las Vegas, NV 89193-8521

Correspondence Control

D. C. Ânderson

D. K. Cowser

D. D. Madsen

K. A. Quintana

S. J. Nacht 


\title{
DISTRIBUTION LIST (continued)
}

\author{
Uncontrolled Copies
}

\section{IT Corporation}

P. O. Box 93838 , M/S 439

Las Vegas, NV 89193-3838

K. C. Beach

M. E. Todd 